\title{
The Middle Miocene climate as modelled in an atmosphere-ocean-biosphere model
}

\author{
M. Krapp ${ }^{1,2}$ and J. H. Jungclaus ${ }^{1}$ \\ ${ }^{1}$ Max-Planck Institut für Meteorologie, Hamburg, Germany \\ ${ }^{2}$ International Max Planck Research School on Earth System Modelling, Hamburg, Germany \\ Received: 30 May 2011 - Published in Clim. Past Discuss.: 17 June 2011 \\ Revised: 27 September 2011 - Accepted: 30 September 2011 - Published: 8 November 2011
}

\begin{abstract}
We present simulations with a coupled atmosphere-ocean-biosphere model for the Middle Miocene 15 million years ago. The model is insofar more consistent than previous models because it captures the essential interactions between ocean and atmosphere and between atmosphere and vegetation. The Middle Miocene topography, which alters both large-scale ocean and atmospheric circulations, causes a global warming of $0.7 \mathrm{~K}$ compared to present day. Higher than present-day $\mathrm{CO}_{2}$ levels of 480 and $720 \mathrm{ppm}$ cause a global warming of 2.8 and $4.9 \mathrm{~K}$. The associated water vapour feedback enhances the greenhouse effect which leads to a polar amplification of the warming. These results suggest that higher than present-day $\mathrm{CO}_{2}$ levels are necessary to drive the warm Middle Miocene climate, also because the dynamic vegetation model simulates a denser vegetation which is in line with fossil records. However, we do not find a flatter than present-day equator-to-pole temperature gradient as has been suggested by marine and terrestrial proxies. Instead, a compensation between atmospheric and ocean heat transport counteracts the flattening of the temperature gradient. The acclaimed role of the large-scale ocean circulation in redistributing heat cannot be supported by our results. Including full ocean dynamics, therefore, does not solve the problem of the flat temperature gradient during the Middle Miocene.
\end{abstract}

\section{Introduction}

The climate of the Middle Miocene was the warmest period of the last 25 million years, contrasting the Cenozoic long term cooling (Zachos et al., 2001). According to reconstructions based on terrestrial and marine proxies, the equator-to-

Correspondence to: M. Krapp

(mario.krapp@zmaw.de) pole temperature gradient was reduced both over land and ocean (Nikolaev, 2006; Bruch et al., 2007). The climate in Europe was warmer and more humid (Böhme et al., 2011; Bruch et al., 2010). Even in the Sahara region, conditions were humid and desert regions were far less extended than today (Senut et al., 2009). The continents were densely wooded; evergreen forests expanded to at least $45^{\circ} \mathrm{N}$, and boreal forest expanded northward as far as the Arctic circle (Wolfe, 1985; Williams et al., 2008).

Reconstructions for atmospheric $\mathrm{CO}_{2}$ levels estimate values between $180 \mathrm{ppm}$ up to $550 \mathrm{ppm}$ (Pagani et al., 1999; Royer et al., 2001; Kürschner et al., 2008). Translated into radiative forcing, the uncertainty accounts for about $2.6 \mathrm{~W} \mathrm{~m}^{-2}$ for the direct effect of $\mathrm{CO}_{2}$ only (Myhre et al., 1998). In a recent model study, the possible range of atmospheric $\mathrm{CO}_{2}$ levels for the Middle Miocene was suggested to be between 460 and 580 ppm (You et al., 2009).

Previous modelling studies for the Middle Miocene used atmosphere general circulation models (GCMs) with either prescribed sea surface temperatures (SSTs) or a mixed-layer ocean (You et al., 2009; Tong et al., 2009; Herold et al., 2010). Except for Herold et al. (2010) who prescribed SSTs based on proxy data, none of these models was able to reproduce the flatter equator-to-pole temperature gradient. What these studies have in common is that they lack the dynamics of an ocean GCM. Atmospheric GCMs can take into account tectonic changes such as mountain uplift, but they cannot account for oceanic gateway re-configurations and associated changes in circulation, heat, and freshwater transport. For the last 25 million years, when atmospheric $\mathrm{CO}_{2}$ was relatively low, both mountain uplift and oceanic gateway re-configurations may have triggered large-scale shifts in climate (Zachos et al., 2001). In a more advanced setup, Henrot et al. (2010) forced their model with sea surface temperatures obtained from Middle Miocene ocean GCM experiments (Butzin et al., 2011). However, interactions between atmosphere and ocean could not be investigated. 
Our study presents an additional step forward by using a fully coupled atmosphere-ocean-biosphere GCM. We test if the results with the full ocean dynamics are consistent with previous modelling studies, and if we can improve the meridional temperature gradient mismatch. Therefore, we perform a series of experiments and investigate how topography and ocean gateways contribute to a warm Middle Miocene climate and how higher than present-day $\mathrm{CO}_{2}$ levels contribute to a warm Middle Miocene climate.

This paper is organised as follows. Section 2 describes the setup of our GCM and the experimental design. The results for the Middle Miocene mean climates are presented in Sect. 3. The dynamics behind the ocean and atmospheric heat transports are discussed in Sect. 4 and the changes of the large-scale ocean circulation is the matter of interest in Sect. 5. In Sect. 6, we compare our results to marine and terrestrial temperature reconstructions. Section 7 gives a summary and a discussion on our main findings. We conclude in Sect. 8 .

\section{Model set-up and experimental design}

We use the atmosphere-ocean-biosphere general circulation model MPI-ESM. It is a comprehensive Earth-System Model that has been developed at the Max-Planck Institute for Meteorology in Hamburg. The dynamical core of the atmosphere model ECHAM5 is formulated in spherical harmonics (Roeckner et al., 2003). We use ECHAM5 in a T42 truncation, which corresponds to a horizontal grid spacing of $2.8^{\circ}$. ECHAM5 has 19 levels in the vertical, the uppermost being at $10 \mathrm{hPa}$. ECHAM5 incorporates the land surface model JS$\mathrm{BACH}$ that includes a dynamic vegetation module (Raddatz et al., 2007; Brovkin et al., 2009). In JSBACH, each grid cell is divided into tiles, which are covered with eight plant functional types (PFTs). These PFTs are tropical broad-leaf evergreen, tropical broad-leaf deciduous, extra-tropical evergreen, extra-tropical deciduous, rain-green shrubs, deciduous shrubs, C3 grass, and $\mathrm{C} 4$ grass. The vegetation dynamics in JSBACH are based on the assumption that different PFTs compete in terms of their annual net primary production, their natural, and their disturbance-driven mortality (for details, see Brovkin et al., 2009). JSBACH can, therefore, account for temporal and spatial changes of the land-surface albedo determined by the modelled PFTs. The ocean model MPI-OM (Marsland et al., 2003) uses a tripolar curvilinear grid with a quasi-homogeneous horizontal grid spacing of about $1^{\circ}$. MPI-OM has 40 levels in the vertical, which are unequally spaced. The upper $150 \mathrm{~m}$ are resolved within ten levels. MPI-OM incorporates a dynamic-thermodynamic seaice model that follows the descriptions of Hibler and Semtner (Hibler, 1979; Semtner, 1976). MPI-OM and ECHAM5 exchange momentum flux, heat flux, and freshwater flux, as well as sea surface temperatures, sea-ice thickness, sea-ice
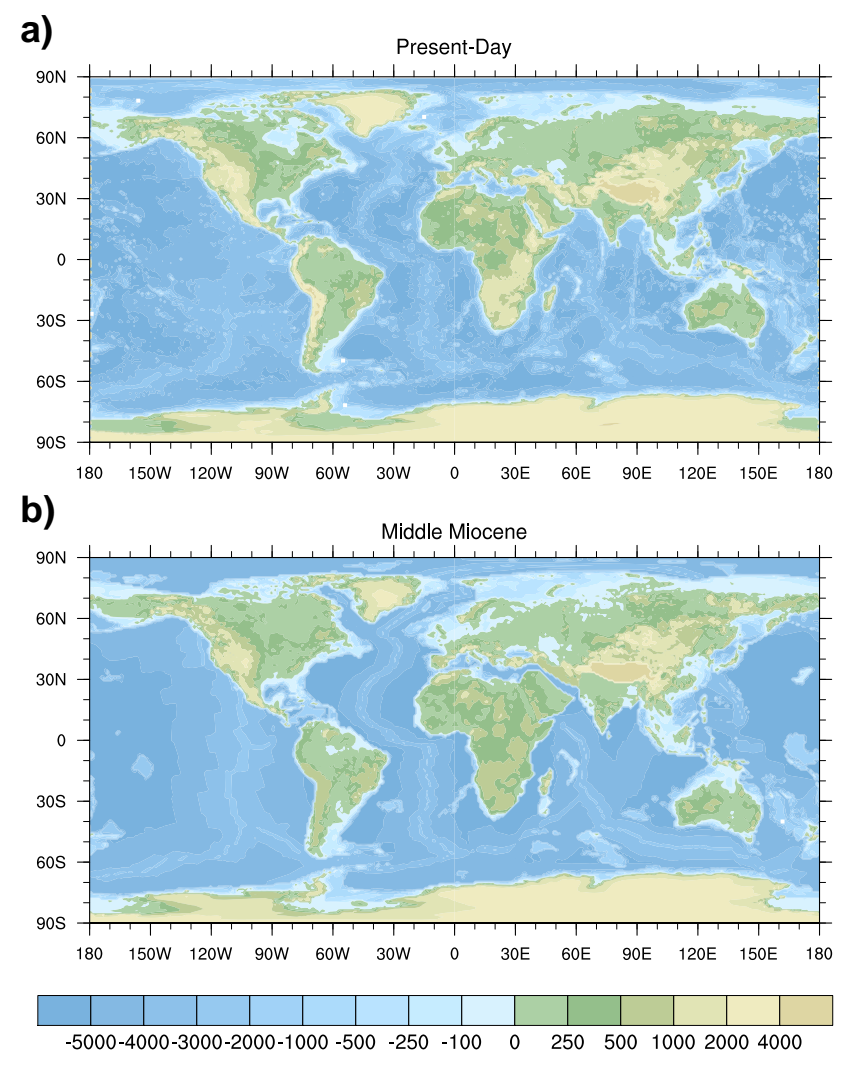

Fig. 1. (a) The present-day topography we use in CTRL, and (b) the Middle Miocene topography we use in MIOC360, MIOC480, and MIOC720 (in m).

fraction, and snow cover on sea-ice once per day via OASIS (Valcke, 2006).

The first two experiments differ in their applied topography (Fig. 1). The palaeotopography is based on a global plate rotation model, and the palaeobathymetry is reconstructed using an age-depth relationship for the oceanic crust with overlaid sediment thicknesses (Herold et al., 2008). Uncertainties for this reconstructed topography are largest in the mountain regions of Andes, Rocky Mountains, and the Tibetan Plateau. Furthermore, the seafloor is relatively smooth compared to present day due to the lack of geological data (for details, see Herold et al., 2008). In contrast to present day, several open ocean gateways connect the major ocean basins, for example, the open Panama Seaway, the Tethys, and a wider Indonesian Through-flow. The atmospheric circulation is also affected by the topography because large mountain regions like the Andes, the Himalayas, the Rocky Mountains, and the Alps are lower compared to present day. We remove the Greenland Ice Sheet in all Middle Miocene experiments, because glaciation on Greenland had started later during the Pliocene (Raymo, 1994). We refer to the experiment with the Middle Miocene topography as MIOC360 and to the experiment with present-day topography as CTRL. 
Table 1. RMSEs with respect to ERA-40 (1979-1993) for temperature $T$ (in ${ }^{\circ} \mathrm{C}$ ), geopotential height $Z$ (in dam), and zonal wind $U$ (in $\mathrm{m} \mathrm{s}^{-1}$ ) at pressure levels 200, 500, and $850 \mathrm{hPa}$, and sea level pressure SLP (in hPa). RMSEs in Roeckner et al. (2006) are for ECHAM5 in T42L19 (same resolution as used here) with respect to ERA-15. The rms differences between ERA-15 and ERA-40 are taken from Table 2 (Roeckner et al., 2006).

\begin{tabular}{lcccccccccc}
\hline variable & T200 & T500 & T850 & Z200 & Z500 & Z850 & SLP & U200 & U500 & U850 \\
\hline CTRL & 6.47 & 1.13 & 2.46 & 7.98 & 4.41 & 2.08 & 3.99 & 4.71 & 2.61 & 2.10 \\
Roeckner et al. (2006) & 5.12 & 1.00 & 2.02 & 7.04 & 3.25 & 1.93 & 2.55 & 4.48 & 2.37 & 1.92 \\
ERA-40 & 0.68 & 0.40 & 1.08 & 0.83 & 0.67 & 0.56 & 1.25 & 0.73 & 0.85 & 0.61 \\
\hline
\end{tabular}

In both CTRL and MIOC360 we prescribe present-day $\mathrm{CO}_{2}$ levels of $360 \mathrm{ppm}$.

Even though present-day climate is in a transient state under increasing greenhouse gas concentration, we choose to perform a control integration with $360 \mathrm{ppm}$ for two reasons. First, we compare the model performance with a standalone version of ECHAM5 validated against re-analysis data (Roeckner et al., 2006). The root mean square errors (RMSE) for temperature, geopotential height, and sea level pressure with respect to ERA-40 re-analysis data (Uppala et al., 2005) are shown in Table 1. Compared to a stand-alone version of ECHAM5 that is forced with sea surface temperatures, the RMSEs in CTRL are larger. CTRL is based on the fully coupled MPI-ESM that includes an ocean and a vegetation model. Because of this increased complexity, the sources for errors might increase. Second, previous modelling studies have already hinted at higher than pre-industrial atmospheric $\mathrm{CO}_{2}$ levels for the Middle Miocene (You et al., 2009; Tong et al., 2009).

In the last two experiments we assess the uncertainties of atmospheric $\mathrm{CO}_{2}$ and prescribe higher than modern atmospheric $\mathrm{CO}_{2}$ levels for the Middle Miocene. The experiment where we prescribe a $\mathrm{CO}_{2}$ level of $480 \mathrm{ppm}$ will be referred to as MIOC480. The experiment where we prescribe a $\mathrm{CO}_{2}$ level of $720 \mathrm{ppm}$ will be referred to as MIOC720. All experiments share the same present-day concentration of methane $(650 \mathrm{ppb})$ and nitrous oxide $(270 \mathrm{ppb})$. Orbital parameters are also kept at their present-day values.

CTRL is integrated for $2100 \mathrm{yr}$ to reach quasi-equilibrium, MIOC360 for $2300 \mathrm{yr}$. Based on MIOC360, MIOC720 is then integrated for $2000 \mathrm{yr}$. After this integration we decrease the $\mathrm{CO}_{2}$ level to $480 \mathrm{ppm}$ and run the simulation for another $1000 \mathrm{yr}$ to reach equilibrium in MIOC480. We calculate the maximum drift of deep ocean temperatures to estimate how well each experiment is equilibrated. For temperatures below $2000 \mathrm{~m}$, the drift is $0.2 \mathrm{mK} \mathrm{yr}^{-1}$ in CTRL, $-0.1 \mathrm{mK} \mathrm{yr}^{-1}$ in MIOC $360,-1.5 \mathrm{mK} \mathrm{yr}^{-1}$ in MIOC480, and $0.9 \mathrm{mK} \mathrm{yr}^{-1}$ in MIOC720. For the following analysis we use the last $100 \mathrm{yr}$ of each experiment.

\section{The mean Middle Miocene climate}

The Middle Miocene topography allows for a large-scale reorganisation of both atmosphere and ocean circulation. Mountain regions affect the atmosphere, ocean gateways and bottom topography affects the ocean. Higher than presentday $\mathrm{CO}_{2}$ alters the radiation balance, which determines the top of atmosphere heat flux and therefore the poleward heat transport. $\mathrm{CO}_{2}$ also alters surface temperatures as well as the hydrological cycle, both being factors that determine the vegetation.

In the following, we compare our results to previous model studies for the Middle Miocene according to their model sensitivity to a doubling of $\mathrm{CO}_{2}$. Therefore, we shortly describe the setups of these previous experiments keeping the experiment names as in the respective study. You et al. (2009) performed atmospheric GCM experiments in which they prescribed a medium (SM) and a high (SH) meridional sea surface temperature gradient. In each of these $\mathrm{SM}$ and $\mathrm{SH}$ experiments, atmospheric $\mathrm{CO}_{2}$ was prescribed with $350 \mathrm{ppm}$ (SM_350 and SH_350) and 700 ppm (SM_700 and SH_700). Tong et al. (2009) performed atmospheric GCM experiments coupled to a slab ocean with prescribed atmospheric $\mathrm{CO}_{2}$ of $355 \mathrm{ppm}\left(\mathrm{MidCO}_{2}\right)$ and $700 \mathrm{ppm}\left(\mathrm{HighCO}_{2}\right)$. Henrot et al. (2010) performed atmospheric GCM experiments forced by Middle Miocene SSTs from an ocean model (Butzin et al., 2011) in which $\mathrm{CO}_{2}$ was prescribed to 200,280 , and $500 \mathrm{ppm}$ (MM3, MM2, MM4), and in which a modelled Middle Miocene vegetation was taken into account (MM4-veg).

\subsection{Global changes}

The global annual mean temperature changes only slightly when applying the Middle Miocene topographic boundary conditions (Table 2). In MIOC360, the annual mean temperature is $15.0^{\circ} \mathrm{C}, 0.7 \mathrm{~K}$ higher compared to $14.3^{\circ} \mathrm{C}$ in CTRL. Although the zonal mean temperatures differences hardly show up (Fig. 2a), they can be very large on the regional scale (Fig. 3a). Many of the warming patterns can be attributed to the Middle Miocene land elevation that is on average $150 \mathrm{~m}$ lower than today. Because of the lower elevation, the continental warming is much larger than the warming over the ocean, $1.2 \mathrm{~K}$ over land compared to $0.3 \mathrm{~K}$ over 
Table 2. Global mean climate parameters for all experiments. Sea ice parameters are calculated for the Northern Hemisphere.

\begin{tabular}{lcccc}
\hline climate parameter & CTRL & MIOC360 & MIOC480 & MIOC720 \\
\hline 2 m air temperature in ${ }^{\circ} \mathrm{C}$ & 14.3 & 15.0 & 17.1 & 19.2 \\
global surface temperature in ${ }^{\circ} \mathrm{C}$ & 15.1 & 15.8 & 17.7 & 19.8 \\
land surface temperature in ${ }^{\circ} \mathrm{C}$ & 9.3 & 10.5 & 12.9 & 15.7 \\
sea surface temperature in ${ }^{\circ} \mathrm{C}$ & 18.0 & 18.3 & 19.8 & 21.4 \\
total precipitation in $\mathrm{mm} \mathrm{a}^{-1}$ & 1082 & 1080 & 1103 & 1131 \\
total cloud cover & 0.617 & 0.616 & 0.604 & 0.591 \\
sea level pressure in $\mathrm{hPa}$ & 1011 & 1004 & 1004 & 1004 \\
vertically integrated water vapour in $\mathrm{kg} \mathrm{m}^{-2}$ & 26.3 & 26.8 & 30.5 & 35.8 \\
long-wave emissivity & 0.582 & 0.580 & 0.569 & 0.557 \\
planetary albedo & 0.320 & 0.317 & 0.312 & 0.306 \\
sea ice area (Mar) in $10^{6} \mathrm{~km}^{2}$ & 14.9 & 14.3 & 11.7 & 9.9 \\
sea ice area (Sep) in $10^{6} \mathrm{~km}^{2}$ & 6.7 & 4.6 & 1.2 & 0.17 \\
sea ice volume (Mar) in $10^{3} \mathrm{~km}^{3}$ & 35.9 & 21.7 & 13.3 & 8.4 \\
sea ice volume (Sep) in $10^{3} \mathrm{~km}^{3}$ & 16.1 & 4.6 & 0.4 & 0.07 \\
global forest cover in $10^{6} \mathrm{~km}^{2}$ & 57.9 & 59.5 & 63.4 & 63.7 \\
global desert cover in $10^{6} \mathrm{~km}^{2}\left(55^{\circ} \mathrm{S}-55^{\circ} \mathrm{N}\right)$ & 17.0 & 15.3 & 14.5 & 16.4 \\
\hline
\end{tabular}

a)

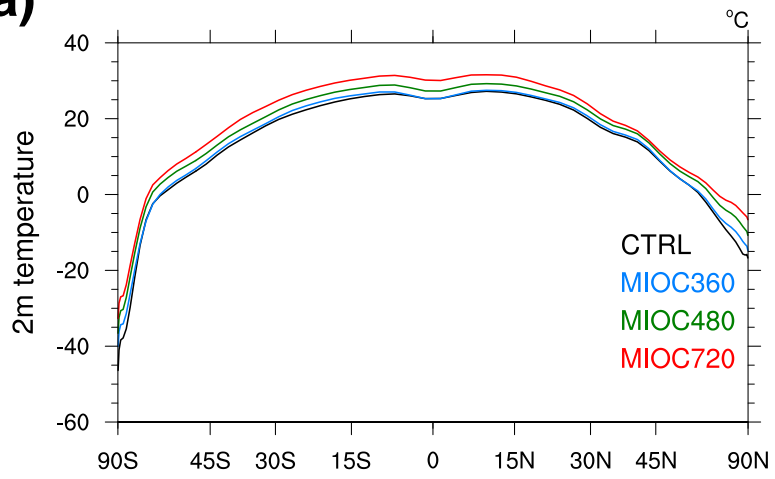

c)

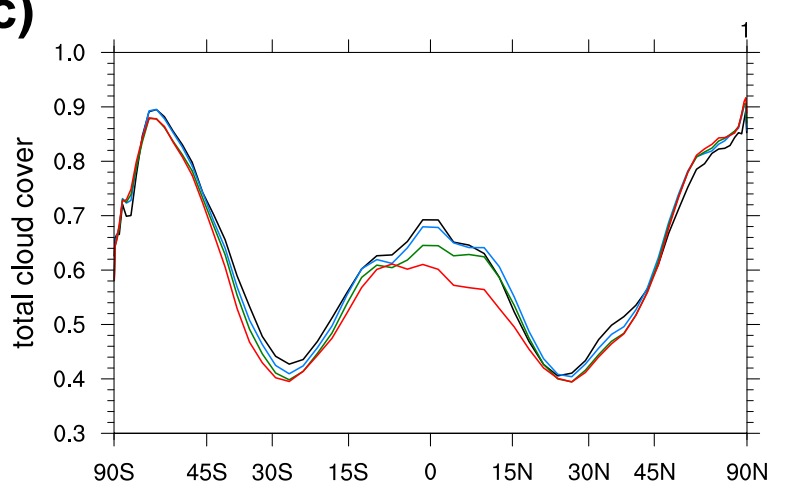

b)

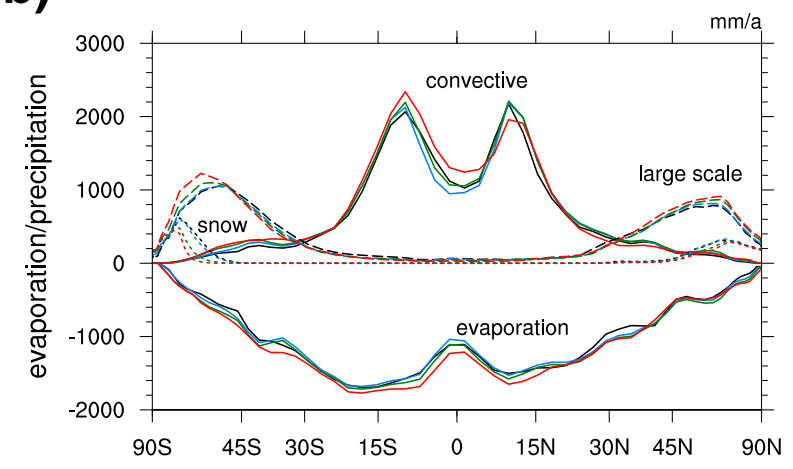

d)

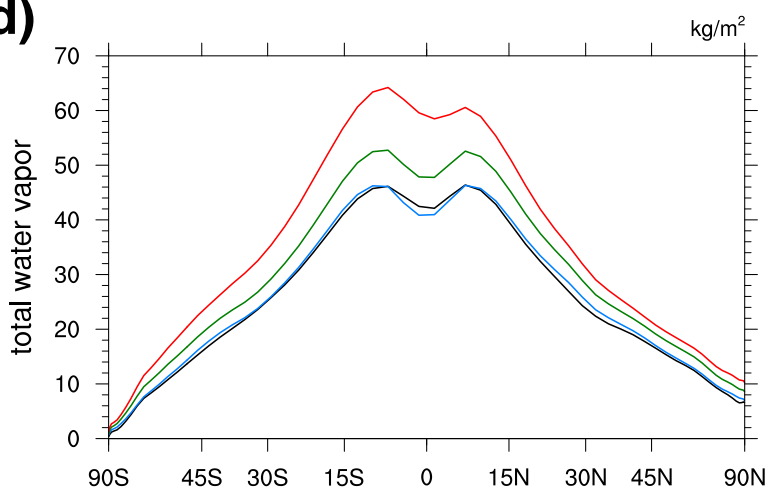

Fig. 2. (a) Zonally averaged $2 \mathrm{~m}$ air temperature (in ${ }^{\circ} \mathrm{C}$ ). (b) Zonally averaged convective precipitation, large-scale precipitation, snow fall, and evaporation (in $\mathrm{mm} \mathrm{a}^{-1}$ ). (c) Zonally averaged cloud cover. (d) Zonally averaged total water vapour content of the atmosphere (in $\mathrm{kg} \mathrm{m}^{-2}$ ). 
a)

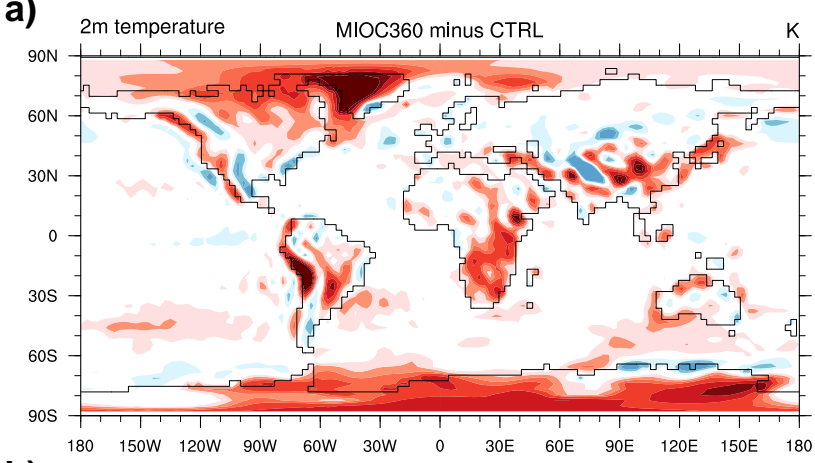

b)

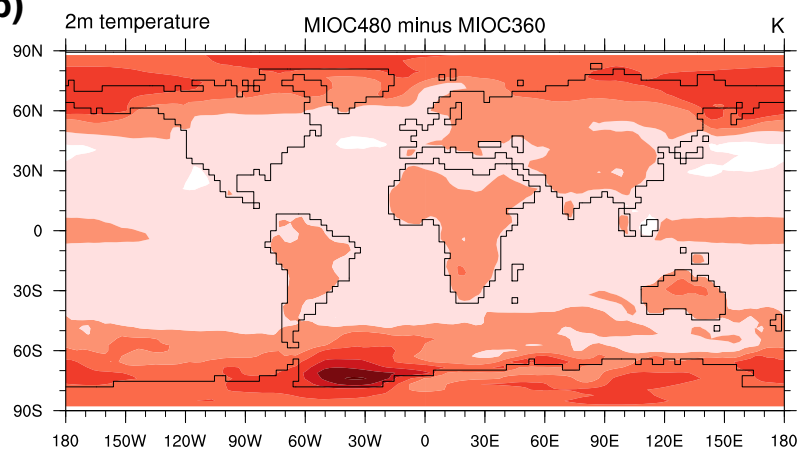

c)

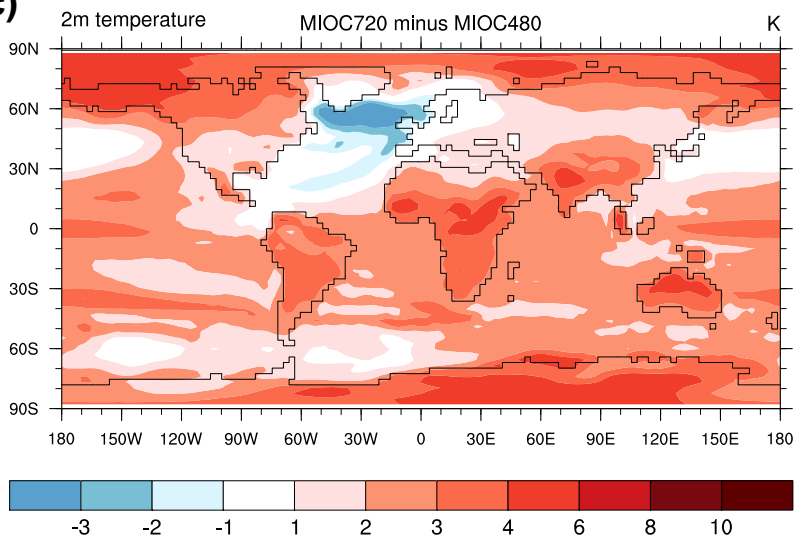

Fig. 3. Differences in $2 \mathrm{~m}$ air temperature between (a) MIOC 360 and CTRL, (b) MIOC480 and MIOC360, and (c) between MIOC720 and MIOC480 (in K).

ocean (Table 2). The mean temperatures over these lower regions in MIOC360 are larger than today, for example up to $15 \mathrm{~K}$ over Greenland, 2 to $4 \mathrm{~K}$ over Antarctica, or up to $7 \mathrm{~K}$ over the South African plateau. Assuming the global lapse rate to vary between the the environmental lapse rate of $6.5 \mathrm{~K} \mathrm{~km}^{-1}$ and the dry adiabatic lapse rate of $9.8 \mathrm{~K} \mathrm{~km}^{-1}$, the lower elevation of $150 \mathrm{~m}$ would account for a warming between 1.0 and $1.5 \mathrm{~K}$, which agrees with the continental warming of $1.2 \mathrm{~K}$. The warming in MIOC360 can, therefore, be explained by the generally lower continents.

The warming in MIOC360 is presumably too small, especially in the ocean. Therefore, and due to the uncertainty in the reconstructed atmospheric $\mathrm{CO}_{2}$, we apply higher than present-day $\mathrm{CO}_{2}$ levels of 480 and $720 \mathrm{ppm}$ in MIOC480 and MIOC720. The $\mathrm{CO}_{2}$-induced warming in MIOC480 and MIOC720 is more homogeneous than the localised topographic effects (Fig. 3b and c). Global annual mean temperatures in MIOC480 and MIOC720 are $17.1{ }^{\circ} \mathrm{C}$ and $19.2^{\circ} \mathrm{C}$, corresponding to warming of $2.8 \mathrm{~K}$ and $4.9 \mathrm{~K}$ compared to CTRL (Table 2). Except for the high latitudes, warming is more pronounced over land than over the ocean in all experiments. Polar amplification is already advanced in MIOC360 but intensifies under stronger greenhouse-gas forcing. Seaice cover is reduced in all Miocene experiments and the reduction is strongest during boreal summer (Table 2). Icealbedo feedback amplifies the warming at high latitudes because more short-wave radiation is absorbed that can warm the surface ocean. Furthermore, less summer sea-ice amplifies the warming during the following cold season, because the missing sea ice cannot act as an insulator for the ocean that loses its heat to the atmosphere.

According to the Clausius-Clapeyron relation, a warmer atmosphere can hold more water vapour. The atmospheric water vapour content is significantly larger in MIOC480 and MIOC720 compared to MIOC360 and CTRL (Fig. 2d, Table 2). The hydrological cycle enhances; the annual mean precipitation in MIOC480 and MIOC720 increases by 21 and $49 \mathrm{~mm} \mathrm{a}^{-1}$ compared to CTRL, whereas in MIOC360 the annual mean precipitation of $1080 \mathrm{~mm} \mathrm{a}^{-1}$ is comparable to $1082 \mathrm{~mm} \mathrm{a}^{-1}$ in CTRL. In MIOC360, however, the precipitation pattern changes are more diverse than due to the $\mathrm{CO}_{2}$ as in MIOC480 (Fig. 4). Over Eurasia, rainfall increases in MIOC360, while it decreases over Africa and over the Americas. The increase over Europe is in agreement with reconstructions of the mean annual precipitation (Bruch et al., 2010). Over the equatorial Pacific, precipitation decreases between $10^{\circ} \mathrm{S}$ and $10^{\circ} \mathrm{N}$, but increases poleward of $10^{\circ} \mathrm{S} / \mathrm{N}$. The overall decrease over the Southern Hemisphere is mainly due to a reduction in convective precipitation (Fig. 2b). In MIOC480, precipitation increases over large parts of the Southern Ocean; the largest increase occurs over the western Pacific warm pool. Precipitation decreases over the Panama Seaway region, over the Indian Ocean, and over Australia. The same patterns of precipitation change evolve in MIOC720, although further amplified. Precipitation decreases over the tropics in both MIOC480 and MIOC720 due to less cloud cover (Fig. 2c), whereupon an overall reduction is in line with a future global warming (Trenberth and Fasullo, 2009).

\subsection{Land cover changes}

The important factors that determine the vegetation cover are radiation, precipitation, and atmospheric $\mathrm{CO}_{2}$. Changes in these climate parameters evoke responses of the vegetation cover that affect the climate system in terms of surface albedo, roughness length, moisture and heat fluxes or runoff. In our experimental setups, we intentionally change the 

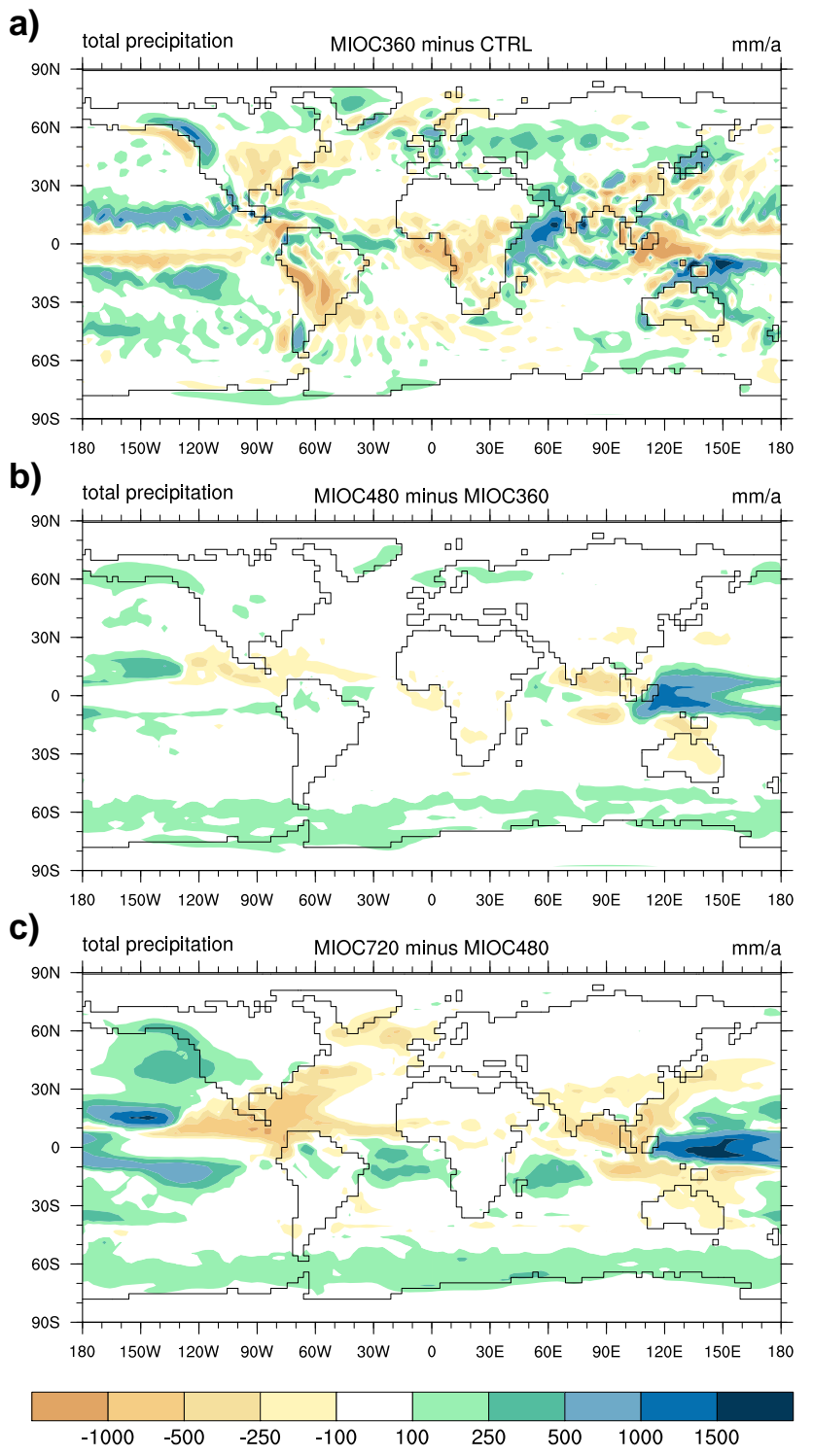

Fig. 4. Differences in total precipitation between (a) MIOC360 and CTRL, (b) MIOC480 and MIOC360, and (c) between MIOC720 and MIOC480 (in $\mathrm{mm} \mathrm{a}^{-1}$ ).

topography and prescribe higher than present atmospheric $\mathrm{CO}_{2}$ levels. While the topography changes the local radiation balance and shifts precipitation patterns, an enhanced hydrological cycle and a stronger greenhouse effect can be attributed to higher $\mathrm{CO}_{2}$.

Vegetation starts to occupy regions where the land ice has been removed, for example over Greenland (Fig. 5). Highlatitude warming and higher $\mathrm{CO}_{2}$ levels support a northward expansion of boreal forests. In MIOC480 and MIOC720, global forest cover is largest (Table 2, Fig. $5 \mathrm{c}$ and d). The large forest cover and the northward extension of forest is in line with vegetation reconstructions (Wolfe, 1985). Unfortunately, the vegetation module in JSBACH cannot account for
Table 3. Model sensitivity to a doubling of atmospheric $\mathrm{CO}_{2}$ for global mean temperature $T$ (in ${ }^{\circ} \mathrm{C}$ ) and precipitation $P$ (in $\mathrm{mm} \mathrm{a}^{-1}$ ). The equilibrium climate sensitivity and transient climate response, respectively, according to the IPCC (AR4) report is $3.4 \mathrm{~K}$ and $2.2 \mathrm{~K}$ for ECHAM5/MPI-OM, and $2.7 \mathrm{~K}$ and $1.5 \mathrm{~K}$ for CCSM3. The average climate sensitivity of all IPCC models is $3.2 \mathrm{~K} \pm 0.7 \mathrm{~K}$ (IPCC, 2007).

\begin{tabular}{lccc}
\hline & $T_{2 \mathrm{~m}}$ & $T_{\text {surf }}$ & $P$ \\
\hline MIOC720-MIOC360, this study & 4.2 & 4.0 & 51 \\
SM_700-SM_350, You et al. (2009) & & 2.0 & \\
SH_700-SH_350, You et al. (2009) & 2.0 & \\
HighCO $_{2}-$ MidCO 2 , Tong et al. (2009) & & 2.2 & 17 \\
MM4-MM2, Henrot et al. (2010) & 2.6 & & 53 \\
MM4-MM3, Henrot et al. (2010) & 4.4 & & 87 \\
MM4-veg-MM2, Henrot et al. (2010) & 3.1 & & 72 \\
MM4-veg-MM3, Henrot et al. (2010) & 4.9 & & 106 \\
\hline
\end{tabular}

changes in soil properties, like field capacity or background albedo. They have to be prescribed with present-day values. Especially in today's extreme regions like the Sahara, vegetation growth is, therefore, restricted or inhibited. Desertification of the Sahara is assumed to have started later during the late Miocene 8-7 Ma ago (Senut et al., 2009). Although the high latitudes are more densely wooded in MIOC720 than in MIOC480, average low latitude temperatures of more than $30^{\circ} \mathrm{C}$ lead to a retreat of tropical rainforest. At its expense, deserts expand. The global desert cover has, therefore, a minimum in MIOC480 (Table 2).

\subsection{Comparison to previous modelling studies}

The warming due to increased $\mathrm{CO}_{2}$ is stronger than in previous Middle Miocene model studies. Because the experimental setup differs in all previous studies, we compare the model sensitivity to a doubling of $\mathrm{CO}_{2}$ in terms of temperature increase or if possible, in terms of precipitation (Table 3). Our model sensitivity (MIOC720 minus MIOC360) in terms of the global mean surface temperature is $4.0 \mathrm{~K}$. It is larger compared to $2.0 \mathrm{~K}$ obtained from You et al. (2009) and $2.2 \mathrm{~K}$ obtained from Tong et al. (2009). However, it is comparable to the model sensitivity of $2.6-4.9 \mathrm{~K}$ obtained from Henrot et al. (2010). In terms of precipitation, our model is less sensitive than the model from Henrot et al. (2010) but more sensitive than the model from Tong et al. (2009). The equilibrium climate sensitivity and transient climate response according to the IPCC (AR4) report is $3.4 \mathrm{~K}$ and $2.2 \mathrm{~K}$ for ECHAM5/MPI-OM, and $2.7 \mathrm{~K}$ and $1.5 \mathrm{~K}$ for CCSM3 (IPCC, 2007), respectively. ECHAM5/MPI-OM is the IPCC-model preceding the MPI-ESM; the model used in Tong et al. (2009) and You et al. (2009) is the land and atmosphere model of CCSM3. The average climate sensitivity of all IPCC models is $3.2 \mathrm{~K} \pm 0.7 \mathrm{~K}$. 
a)

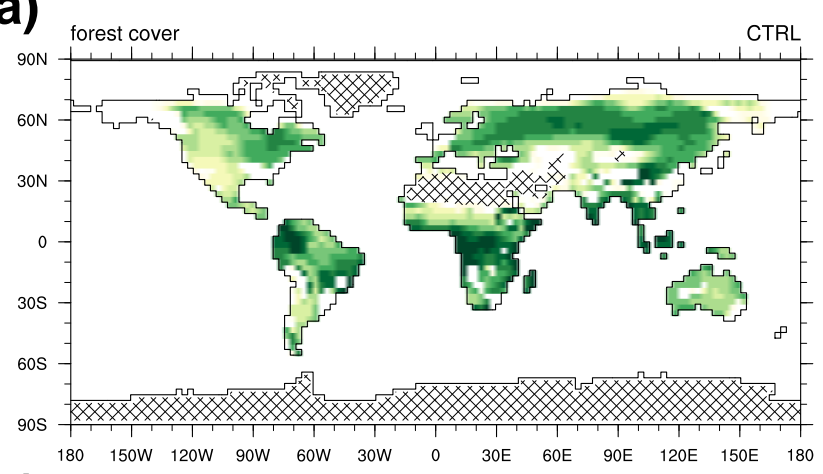

c)

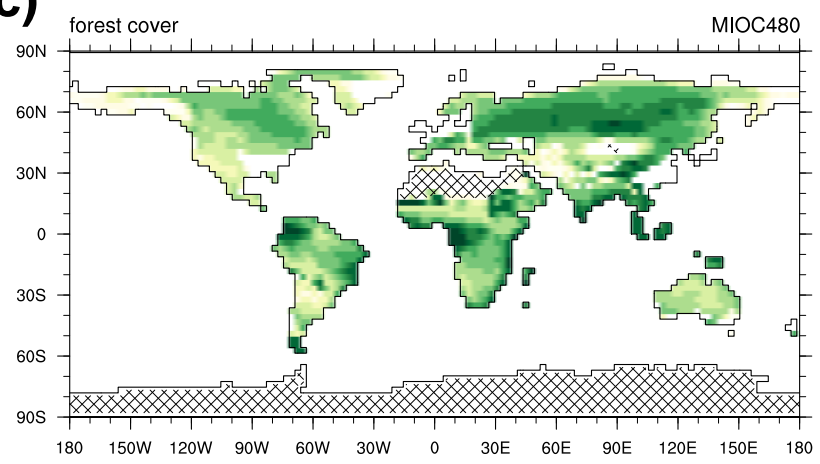

b)

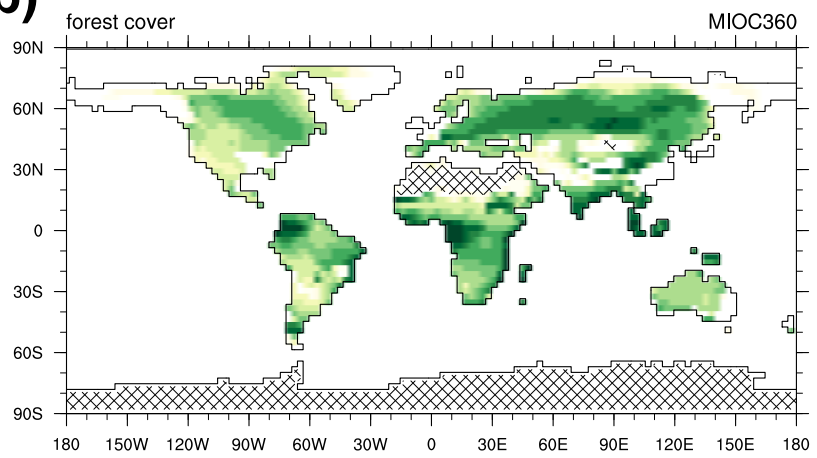

d)

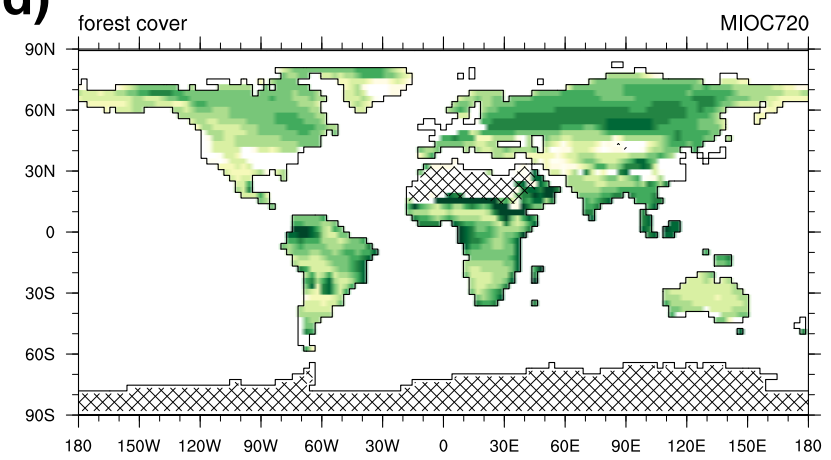

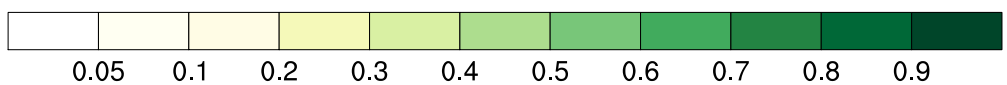

Fig. 5. Forest cover fraction for (a) CTRL, (b) MIOC360, (c) MIOC480, and (d) MIOC720. Crosshatched areas represent desert regions, including land ice, that cover more than $75 \%$.

Climate sensitivity in the Miocene setup appears to be somewhat larger than for present-day conditions, although we acknowledge that the IPCC requirements for sensitivity calculations are a slab ocean setup and a stepwise increase of $\mathrm{CO}_{2}$. However, as shown by Heinemann (2009), ECHAM5/MPI-OM applied to the Paleocene/Eocene has an even higher climate sensitivity of $6.5 \mathrm{~K}$. A higher sensitivity may, therefore, also apply to other past warm climates.

\subsection{A simple one-dimensional EBM}

We now apply a simple one-dimensional energy balance model (EBM) to quantitatively analyse the causes for the temperature differences, following the approach of Heinemann et al. (2009). In radiative equilibrium, Earth's surface temperature $T_{\text {surf }}$ is determined by the long-wave emissivity $\epsilon$, the planetary albedo $\alpha$, and the meridional heat flux divergence $H$ via the energy balance

$I(\phi)[1-\alpha(\phi)]-H(\phi)=\epsilon(\phi) \sigma T_{\text {surf }}^{4}(\phi)$.

$\phi$ is the latitude, $I$ is the latitudinal varying incoming solar radiation, and $\sigma$ is the Stefan-Boltzmann constant. For reasons of readability, we omit the latitude coordinate $\phi$ in the following. We diagnose the EBM parameters $\alpha, H$, or $\epsilon$ from our GCM results to obtain the surface temperature according to Eq. (1). The zonally averaged temperature changes can then be attributed to one of $\alpha, H$, or $\epsilon$, while keeping the other two fixed (Fig. 6). For example, to estimate the warming caused by the MIOC 360 planetary albedo $\alpha$, we leave $H$ and $\epsilon$ as they are in CTRL. The surface temperature difference can then be attributed to differences of the planetary albedo $\alpha$. Individual curves in each plot of Fig. 6 correspond to the individual contribution of $\alpha, H$, and $\epsilon$ to surface temperature changes; their sum corresponds to the total temperature change. The difference between the surface temperature calculated by Eq. (1) and the surface temperature obtained from the GCM is only marginal and mean deviations are smaller than $0.25 \mathrm{~K}$.

The high latitude warming in MIOC360 is caused by a smaller longwave emissivity, meaning that less longwave radiation is emitted at the top of the atmosphere. In the northern high latitudes, this warming is also accomplished by a reduced planetary albedo. In the southern midlatitudes, the warming is mainly caused by a reduced planetary albedo that corresponds to less cloud-cover over this region (Fig. 2c). The reduced cloud cover over the tropics, 

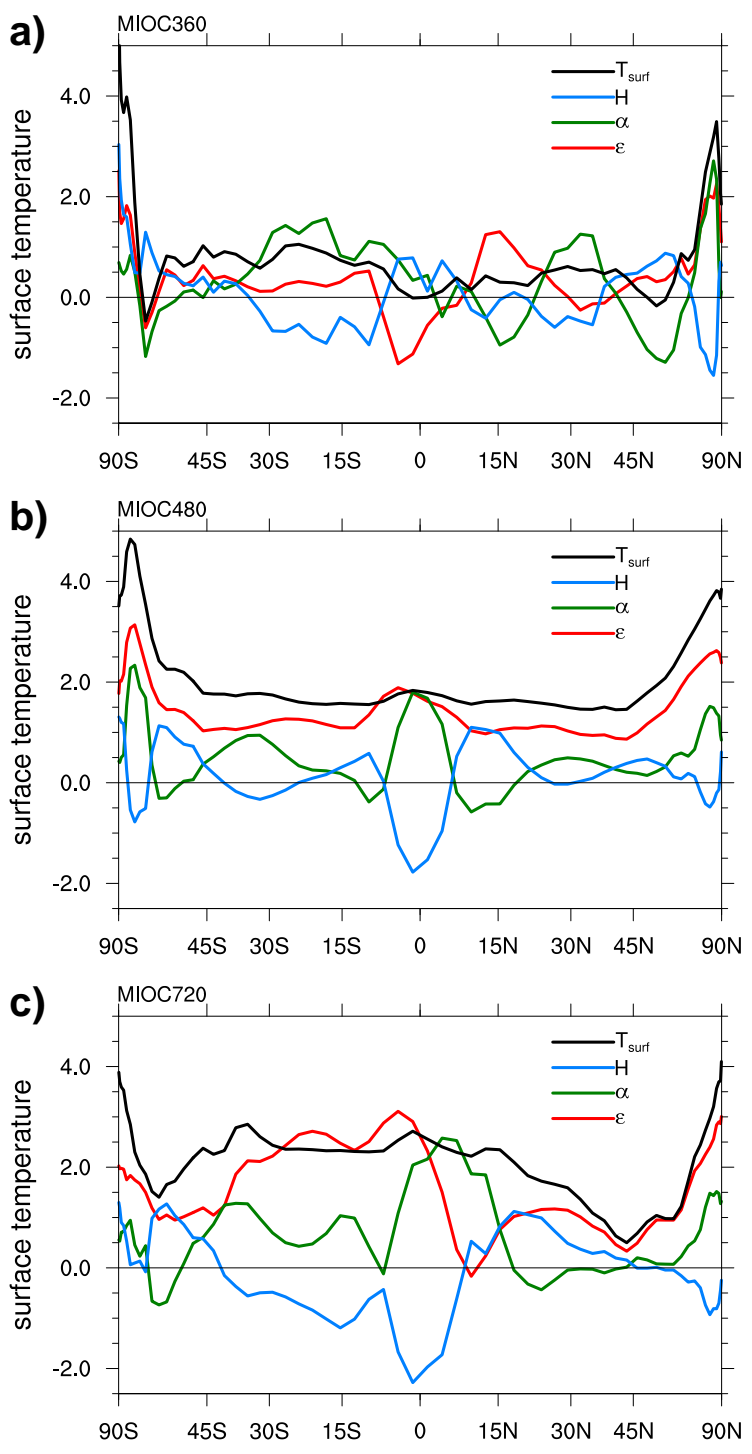

Fig. 6. Contribution of $\alpha, \epsilon$, and $H$ to changes in the zonally averaged surface temperature $T_{\text {surf }}$ according to Eq. (1). Temperature increase in (a) MIOC360 compared to CTRL, (b) MIOC480 compared to MIOC360, and (c) MIOC720 compared to MIOC480.

especially in MIOC480 and MIOC720, leads to enhanced warming, as the peak of $\alpha$ near the equator also reveals. The increased export of heat effectively cools the tropics. The temperature change induced by the heat flux divergence $H$ is, therefore, negative.

Long-wave emissivity $\epsilon$ largely contributes to the $\mathrm{CO}_{2}$ induced warming in MIOC480 and MIOC720. The reduction of $\epsilon$ is in line with the increased water vapour content of the atmosphere (Table 2). The atmosphere in MIOC480 and MIOC720 contains $15 \%$ and $30 \%$ more water vapour than in MIOC360. A decreased long-wave emissivity $\epsilon$ in MIOC480 and MIOC720 means that the greenhouse effect is stronger.
In all experiments, the changes due to albedo changes are nearly compensated by the meridional heat flux divergence. This is specially evident in MIOC720, where $\alpha$ and $H$ are of opposite sign at all latitudes.

We will now focus on the dynamics of the poleward heat transport that is determined by the heat flux divergence term $H$ and on the partitioning between ocean and atmospheric heat transport.

\section{Atmospheric and ocean heat transport}

Changes in the orography alter the large-scale circulation of the atmosphere. Lower and displaced mountain regions deflect low level winds, for example over Greenland, Asia, or western North America (Fig. 7). Low level winds in MIOC480 remain generally unaltered compared to MIOC360 (Fig. 7b). Only in MIOC720, the circulation changes, mainly over the ocean (Fig. 7c). Over the Western Pacific, the trades are stronger, while they are weaker over the Eastern Pacific. Over the North Pacific, the low level winds increase.

Orographic differences also influence the circulation in the upper troposphere, for example midlatitude winter storms (Fig. 8). Winter storms are defined as deviations from the 2.5-6 days bandpass-filtered $500 \mathrm{hPa}$ geopotential height during the winter season (Blackmon, 1976). In MIOC360, they intensify over the Pacific, penetrate inland into the North American continent, and nearly connect with the centre over the Atlantic. Here, they are slightly less intense compared to CTRL. In MIOC480, winter storm activity decreases over the Pacific, while it slightly increases over the Atlantic. In MIOC720, the midlatitude storm activity increases generally.

Midlatitude storm tracks are an efficient way to transport moisture and heat from low to high latitudes and they largely contribute to the poleward heat transport. The total atmospheric poleward heat transport (ahtr) is the zonal and vertical integral of latent heat $(L q)$ and dry static energy $\left(c_{p} T+g z\right)$.

$\operatorname{ahtr}=\frac{1}{g} \iint\left(c_{p} T+g z+L q\right) v \mathrm{~d} x \mathrm{~d} p$

Each term in Eq. (2) can be further decomposed into mean meridional, stationary eddy, and transient eddy heat transport (Fig. $9 \mathrm{~g}-\mathrm{m}$ ). The heat transport by midlatitude storms can then be identified with the transient eddy terms.

The heat transport of moist transient eddies increases in the Northern Hemisphere especially in MIOC720. It also increases in the Southern Hemisphere. A closer look reveals that the Southern Hemisphere transport maximum shifts poleward, while the northward maximum shifts equatorward. Storm tracks are expected to shift poleward in a warming climate. As it has been shown consistently for all IPCC (AR4) models, midlatitude circulation is largely driven by a rise of the tropopause that causes a poleward shift of the storm 
a)

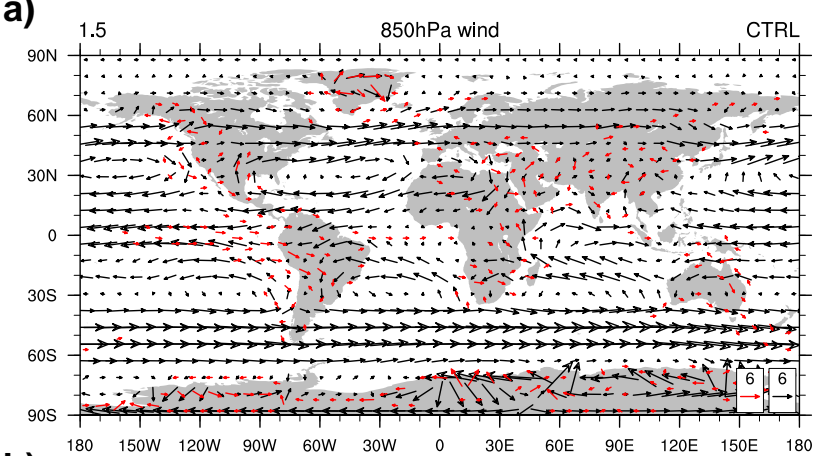

b)

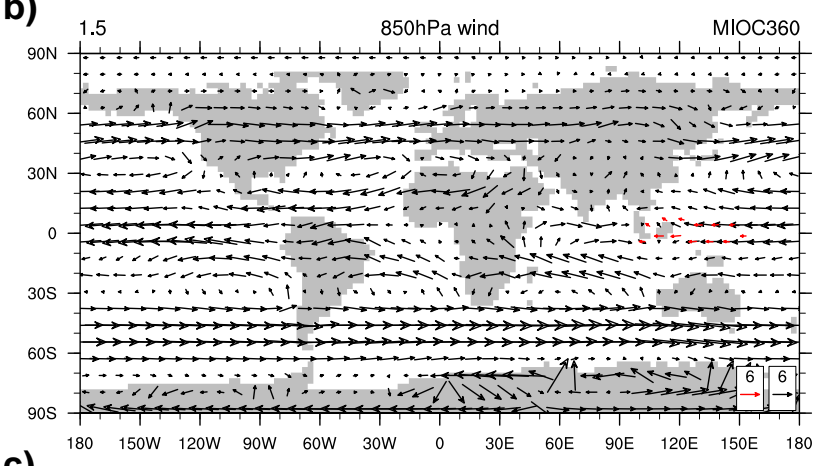

c)

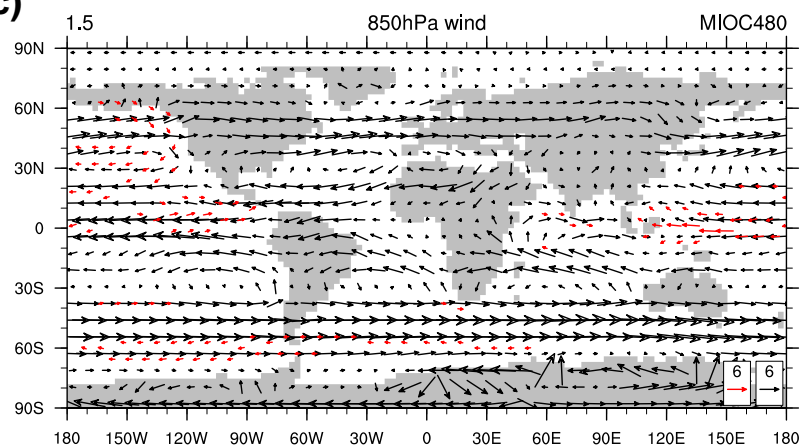

Fig. 7. Low level wind field in (a) CTRL (black arrows) and the difference to MIOC360 (red arrows), (b) MIOC360 and the difference to MIOC480, and (c) MIOC480 and the difference to MIOC720. The lower right reference arrows correspond to a velocity of $6 \mathrm{~m} \mathrm{~s}^{-1}$.

tracks in both hemispheres (Yin, 2005). The equatorward shift of the Northern Hemisphere storm tracks is, therefore, in contrast to what one would expect. Because the only difference between MIOC360 and a modern climate lies in the applied topography we account this asymmetric response to the warming to the Middle Miocene topography.

In MIOC360 and MIOC480, differences of poleward heat transport are small compared to MIOC720. Thus, poleward heat transport does not bring more heat to the higher latitudes to flatten the equator-to-pole temperature gradient. At mid- and high latitudes atmospheric eddies are the dominant drivers of poleward heat transport. However, if eddy heat transport increases, the results show that the payoff is a decreased ocean heat transport. The advective ocean heat trans- port (ohtr) of the potential temperature $\theta$ is

ohtr $=c_{p} \iint \theta \rho v \mathrm{~d} x \mathrm{~d} z$

and can be decomposed into contributions by the meridional overturning and the horizontal gyre circulation (Fig. 9d-f).

\section{Bjerknes compensation}

This compensation between ocean and atmosphere heat transport reflects the so called Bjerknes compensation. It states that if the heat fluxes at the top of the atmosphere and the ocean heat storage do not vary much, then the total heat transport will not vary much (Bjerknes, 1964). Anomalies of atmospheric and ocean heat transport thus compensate and are of opposite sign. Our results show that Bjerknes compensation does not only apply to temporal differences. To some extent, it applies to the different mean climates, because the total heat transport differences are relatively small. For example, the increase of the total heat transport in MIOC720 compared to CTRL has a maximum of only about $0.6 \mathrm{PW}$ in the southern midlatitudes (Fig. 9c). The ocean heat transport in MIOC360 induces a warming of the Southern Ocean between 30 and $60^{\circ} \mathrm{S}$ (Fig. 3a) that is mainly caused by a reduced MOC heat transport (Fig. 9e). In contrast to today, the Atlantic meridional overturning circulation (AMOC) moves heat southward south of the equator.

The ocean heat transport in MIOC720 is significantly altered because of the severe slow-down of the AMOC (Fig. 10). The immediate impact of the reduced northward transport of heat causes a drop in the surface temperature (Fig. 3c). However, this decrease is compensated for by an increase in atmospheric heat transport.

\section{Large-scale ocean circulation}

The large-scale ocean circulation in the Middle Miocene is affected by open ocean gateways like the Panama Seaway and the Tethys. Furthermore, the ocean bathymetry is altered in regions where deepwater is formed, for example the subsidence of the Greenland-Scotland Ridge.

\subsection{Horizontal circulation}

The horizontal circulation is affected by open ocean gateways and changes of the surface wind. In the eastern Atlantic, large water masses from the Indian Ocean enter the Atlantic through the Tethys. This strong westward flow affects the subtropical gyre, reducing its meridional extent (Fig. 11). However, the strength of the subtropical gyre is comparable in CTRL, MIOC360, and MIOC480. The subpolar gyre is also of comparable strength to CTRL, but has a larger extent due to the subsided Greenland-Scotland Ridge, which acts as a natural boundary for the water masses in CTRL. In the equatorial current system of the Atlantic, 

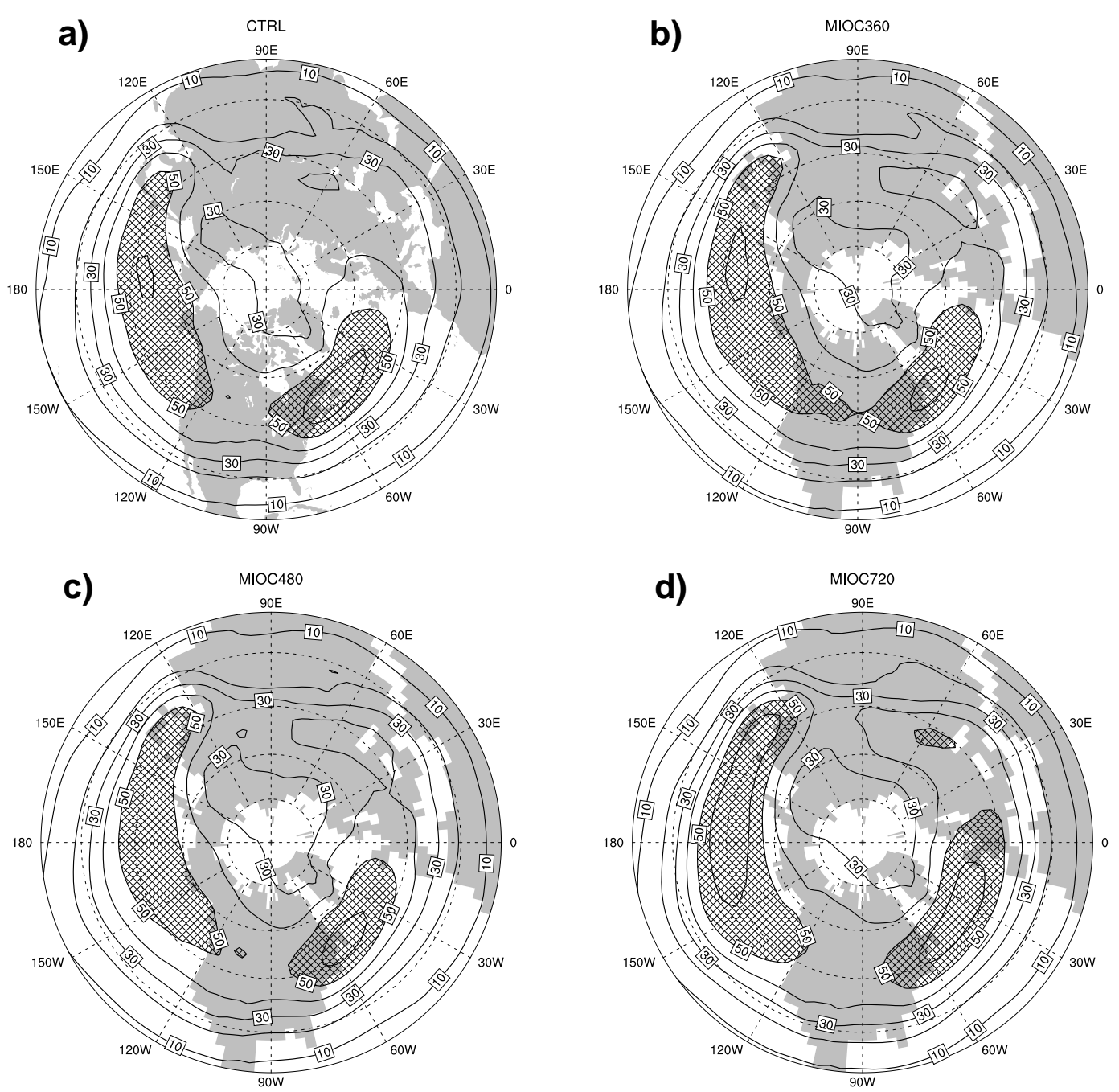

Fig. 8. Winter storm tracks defined as deviations of the 2-6 days bandpass-filtered $500 \mathrm{hPa}$ geopotential height from December to March for (a) CTRL, (b) MIOC360, (c) MIOC480, and (d) MIOC720 (in gpm). Contour interval is every 10 gpm. Stippled regions indicate mean deviations that are larger than $50 \mathrm{gpm}$.

Tethys inflow supports a stronger northern cell that dominates and suppresses the southern cell. Its remains are restricted to a weak western boundary current.

The southward shift of Australia $\left(\sim 8^{\circ}\right)$ has no impcat on the Southern Ocean. The Antarctic Circumpolar Current has a similar structure and is of similar strength in all experiments.

\subsection{Open ocean gateways}

Lateral flow through open ocean gateways changes the water mass properties of the adjacent oceans. Besides the eastward inflow of Indian Ocean water through the Tethys, water from the Pacific enters the Atlantic through the Panama Seaway. These connections allow for a large-scale mixing between the oceans and, therefore, affect their water mass composition (Fig. 12). Through the Panama Seaway, Atlantic deep- water enters the Pacific; Pacific deepwater becomes saltier and denser (Fig. 12b). Near the surface, on the other hand, relatively fresh water is moved from the Pacific into the Atlantic, freshening the Atlantic at the surface (Fig. 12f).

The mixing due to the eastern inflow of Indian Ocean water through the Strait of Gibraltar is well reflected in the composition of Tethys water, it is located between the water masses of Atlantic and Indian Ocean in the T-S diagram (Fig. 12d). Tethys water originates from the Indian Ocean. Along the way into the Atlantic, surface water evaporates and becomes saltier and denser than its original Indian Ocean source. Because the Tethys is not an enclosed basin like the Mediterranean, the deep outflow water is not as dense as in CTRL (Fig. 12e and f). Upper Tethys inflow water through the Gibraltar Strait increases the surface salinity of the Atlantic Ocean, while subsurface water is slightly fresher than the Atlantic. 

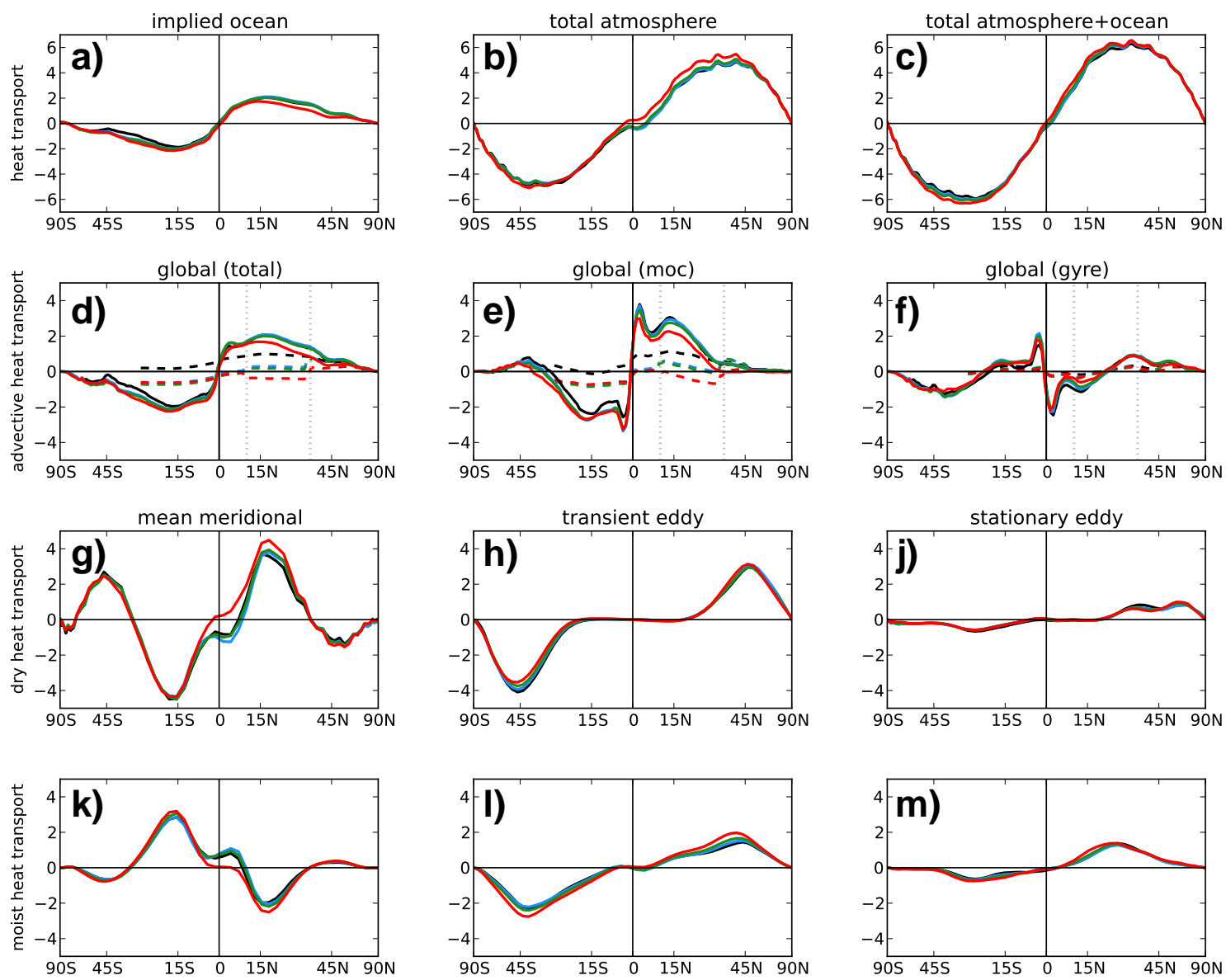

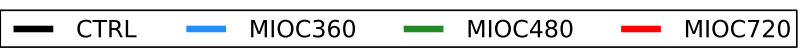

Fig. 9. Northward heat transport by (a) the global ocean, (b) atmosphere, and (c) ocean+atmsophere (in PW). The (implied) ocean heat transport in (a) is based on net surface energy budgets. (d) Total advective ocean heat transport according to Eq. (3) and the transports by (e) the MOC and (f) horizontal gyres. Here, dashed lines show the heat transport in the Atlantic Ocean. Atmospheric heat transport in (b) is calculated according to Eq. (2) and decomposed into (g,k) mean meridional, (h,l) transient eddy, and (j,m) stationary eddy transport.

Water from the Southern Ocean that enters the upper Atlantic Ocean in MIOC360 is relatively salty compared to CTRL and balances the freshening through the Panama Seaway (Fig. 12e and f). As a result the salinity contrast between Pacific and Atlantic increases (contours in Fig. 13). This is contrary to other studies with an open Panama Seaway, where the salinity contrast is reduced and, therefore, leads to a weaker AMOC (Maier-Reimer et al., 1990; Lunt et al., 2007). Instead, the AMOC in MIOC360 is as strong as in CTRL (Fig. 10). Supportive for the AMOC is the sill depth of the Caribbean plateau that is shallower than the deep western boundary current. The deepwater thus returns into the South Atlantic (not shown). That North Atlantic deepwater formation occurred prior to the closure of the Panama Seaway has also been shown in a sensitivity study for different sill depths of the gateway (Nisancioglu et al., 2003).

\subsection{Atlantic meridional overturning circulation}

A necessary condition for deepwater formation in the Atlantic Ocean is the enhanced surface salinity compared to the Pacific Ocean. The salinity contrast between Pacific and Atlantic is determined by the freshwater transport from the Atlantic into the Pacific (Zaucker and Broecker, 1992). Moisture transport across Central America acts as a positive feedback on deepwater formation in the North Atlantic (Leduc et al., 2007). We diagnose the moisture transport from the horizontal velocity field $\boldsymbol{v}$ and the relative humidity $q$ as vertical integral over all pressure levels

$$
\mathbf{T}_{q}=\frac{1}{g} \int q \mathbf{v} \mathrm{d} p .
$$



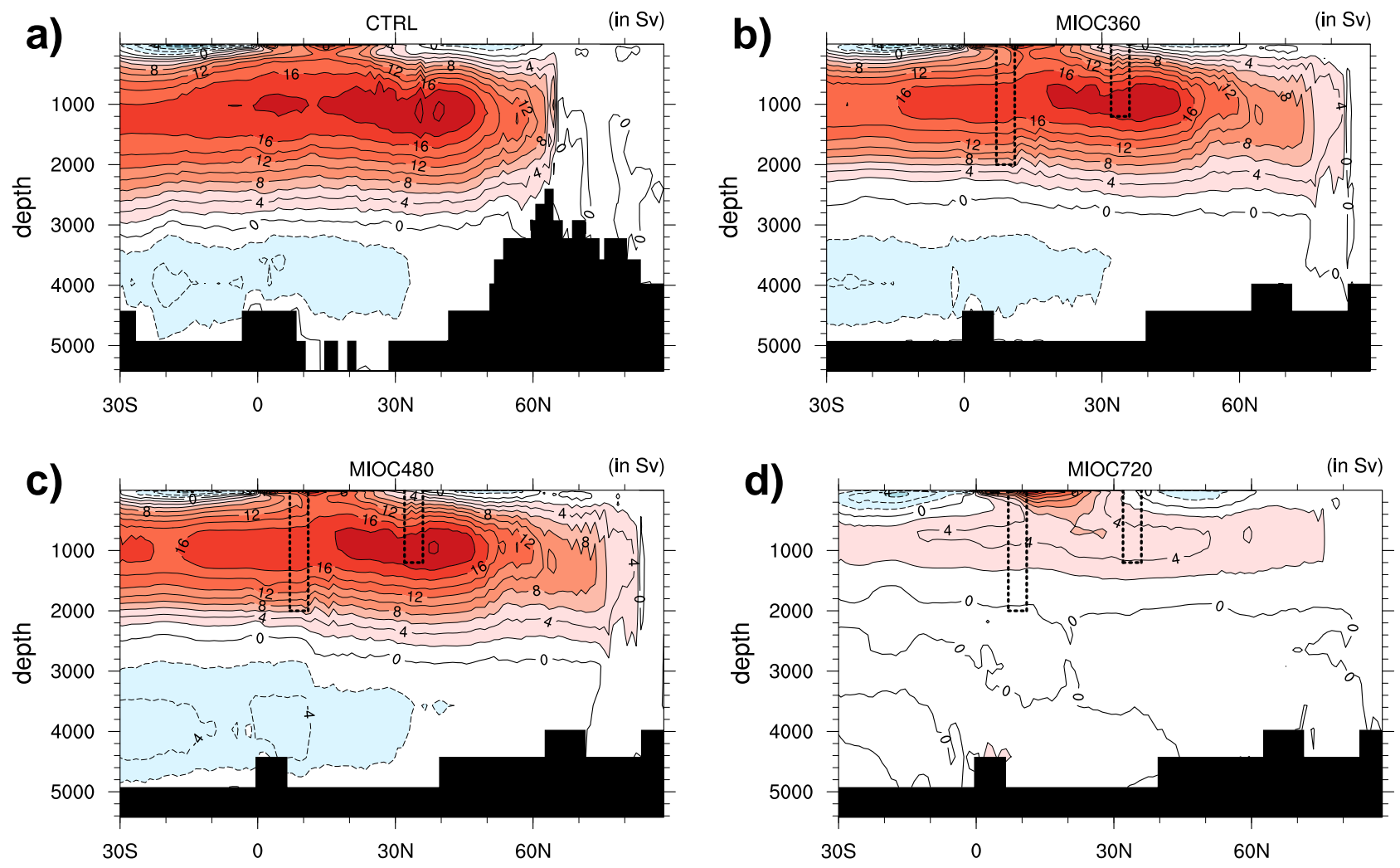

Fig. 10. Meridional overturning circulation in the Atlantic Ocean for (a) CTRL, (b) MIOC360, (c) MIOC480, and (d) MIOC720 (in Sv). Contour interval is $2 \mathrm{~Sv}$. Red corresponds to clockwise circulation; blue corresponds to anti-clockwise circulation. The rectangular boxes indicate the Middle Miocene ocean gateways: Panama Seaway at $10^{\circ} \mathrm{N}$ and Tethys Throughflow at $35^{\circ} \mathrm{N}$. Note the subsided GreenlandScotland Ridge for the Middle Miocene experiments.

Because of the lower Andes in the Miocene setup, moisture transport from the Atlantic into the Pacific increases and further enhances the surface salinity contrast between the basins and strengthens the freshwater-overturning feedback (Fig. 13).

In that sense, the Middle Miocene ocean gateway configuration supports deepwater formation that drives the AMOC. Because of the subsided Greenland-Scotland Ridge, the AMOC in MIOC360 extends more northward than in CTRL (Fig. 10a and b). Even at $80^{\circ} \mathrm{N}$, more than $4 \mathrm{~Sv}$ of Atlantic Ocean water is converted into deep water.

The warming under high $\mathrm{CO}_{2}$ in MIOC720 leads to a collapse of the AMOC. Large parts of the North Atlantic become relatively fresh (Fig. 13) although precipitation decreases (Fig. 4). Larger runoff at the North American East Coast as well as at the North Sea spreads into the North Atlantic, where the surface ocean freshens (not shown) and the ocean stratification increases. Deepwater formation - an important mechanism that drives the AMOC - is inhibited and the circulation slows down to about $4 \mathrm{~Sv}$. This slow-down explains the decrease of the poleward heat transport in the Northern Hemisphere mentioned earlier (Fig. 9).
In a follow-up study, we will assess the uncertainty of ocean bathymetry and investigate how a modern GreenlandScotland Ridge or a shallow eastern Tethys alter the meridional overturning circulation of the Middle Miocene Atlantic Ocean.

\section{Comparison to proxy data}

We compare the modelled palaeo temperatures to proxybased reconstructions for the Middle Miocene. We use terrestrial reconstructions to evaluate land surface temperatures and marine reconstructions to evaluate sea surface temperatures. The sites of the marine proxies are spread all over the oceans, while terrestrial proxies are mainly recovered from the Northern Hemisphere, especially over Europe, East Asia and the coasts of North America (Fig. 14h).

\subsection{Terrestrial proxies}

Terrestrial climate reconstructions based on the coexistence approach estimate the lower and the upper mean annual temperature from plant fossils (Mosbrugger and Utescher, 1997). We use terrestrial temperature data from the 2010 
a)

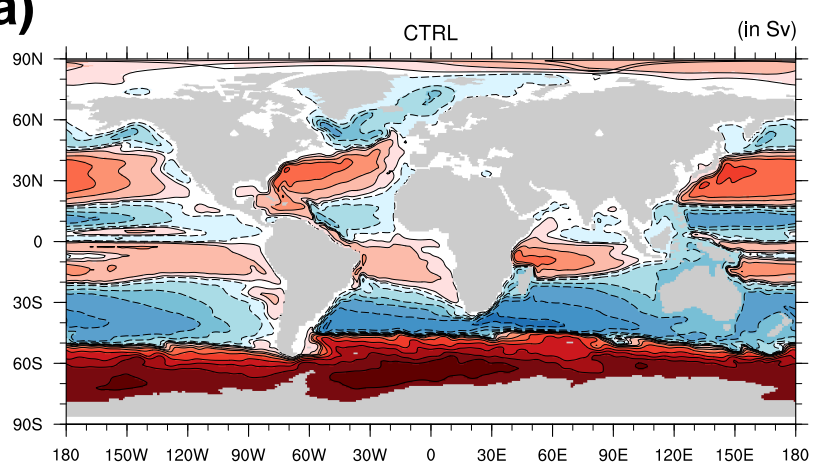

c)

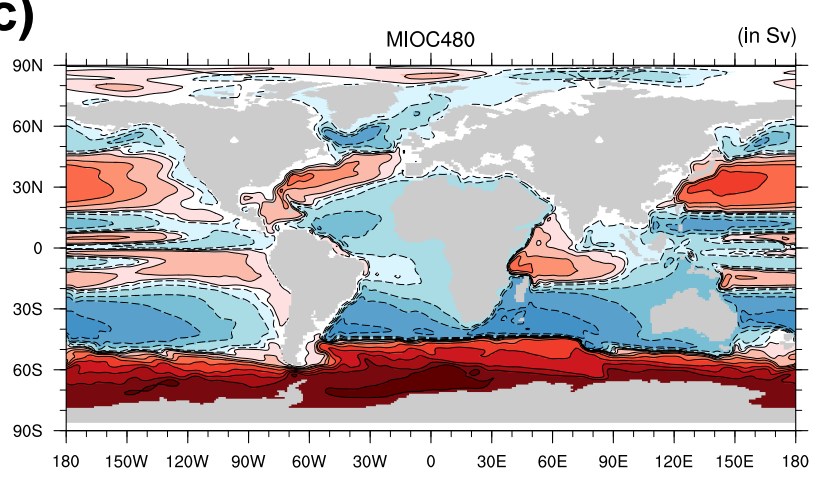

b)

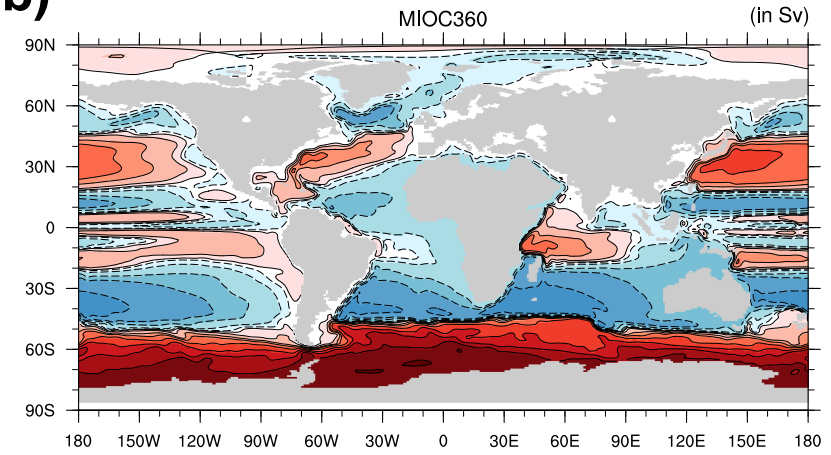

d)

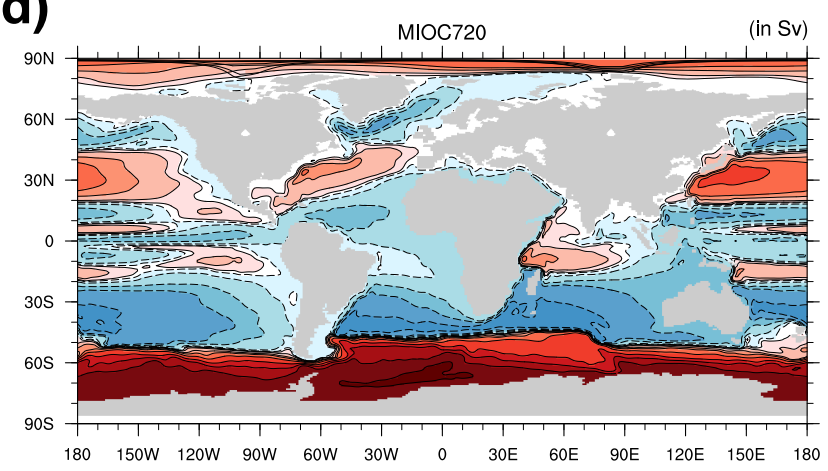

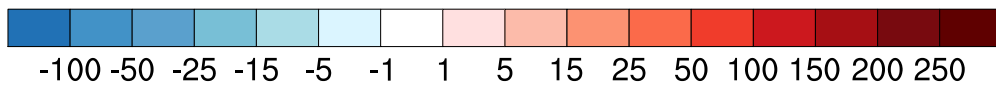

Fig. 11. Horizontal ocean circulation in the Atlantic Ocean in terms of the barotropic streamfunction for (a) CTRL, (b) MIOC360, (c) MIOC480, and (d) MIOC720 (in Sv).

NECLIME data set (Utescher et al., 2011). The data span the period ranging from 16.4 to 11.2 million years ago (Torsten Utescher, personal communication). The data set is also available from PANGAEA, http://www.pangaea.de. We compare reconstructed land surface temperatures obtained from the coexistence approach to our modelled land surface temperatures (Fig. 14a-c).

Most of the proxy data cover the midlatitudes between 30 and $55^{\circ} \mathrm{N} / \mathrm{S}$. For low latitude proxies MIOC360 matches better than MIOC480 or MIOC720. Midlatitude proxies compare well with all experiments. The proxy data confirm that land temperatures were much warmer than today. Warmer high latitude temperatures as in MIOC720 are in better agreement with these proxy reconstructions. The midlatitudes are captured by all palaeo simulations, but cooler than present-day low latitude and warmer than present-day high latitudes cannot be captured together within one single experiment.

\subsection{Marine proxies}

The isotopic composition of seawater, obtained by either $\delta^{18} \mathrm{O}$ or $\mathrm{Mg} / \mathrm{Ca}$ ratios, facilitates a proxy for ocean temper- atures (Emiliani and Edwards, 1953; Hastings et al., 1998). Using the calcite shells of fossil planktonic foraminifera deposited in the ocean sediments, sea surface temperatures (SSTs) for past times can be obtained.

We take Middle Miocene SST reconstruction from several Ocean Drilling Project (ODP) and Deep Sea Drilling Project (DSDP) sites (Table 4). Midlatitude SSTs agree well in all three simulations (Fig. 14b). MIOC360 and MIOC480 match (at least one) proxy-SST for low and high latitudes. The warmer-than-present high latitude SSTs are better captured in MIOC720, but low latitude SSTs are largely overestimated.

\subsection{Model-data agreement}

To evaluate the model-data agreement, we compare the distribution of model-to-data temperature ratios for each grid box (Fig. 14g). Both terrestrial and marine data sets are compared individually for low, mid-, and high latitudes. While for terrestrial proxies MIOC480 and MIOC720 reveal a better agreement, MIOC360 and MIOC480 reveal a better agreement for marine proxies. However, in neither of the experiments do we achieve the desired flatter equator-to-pole 

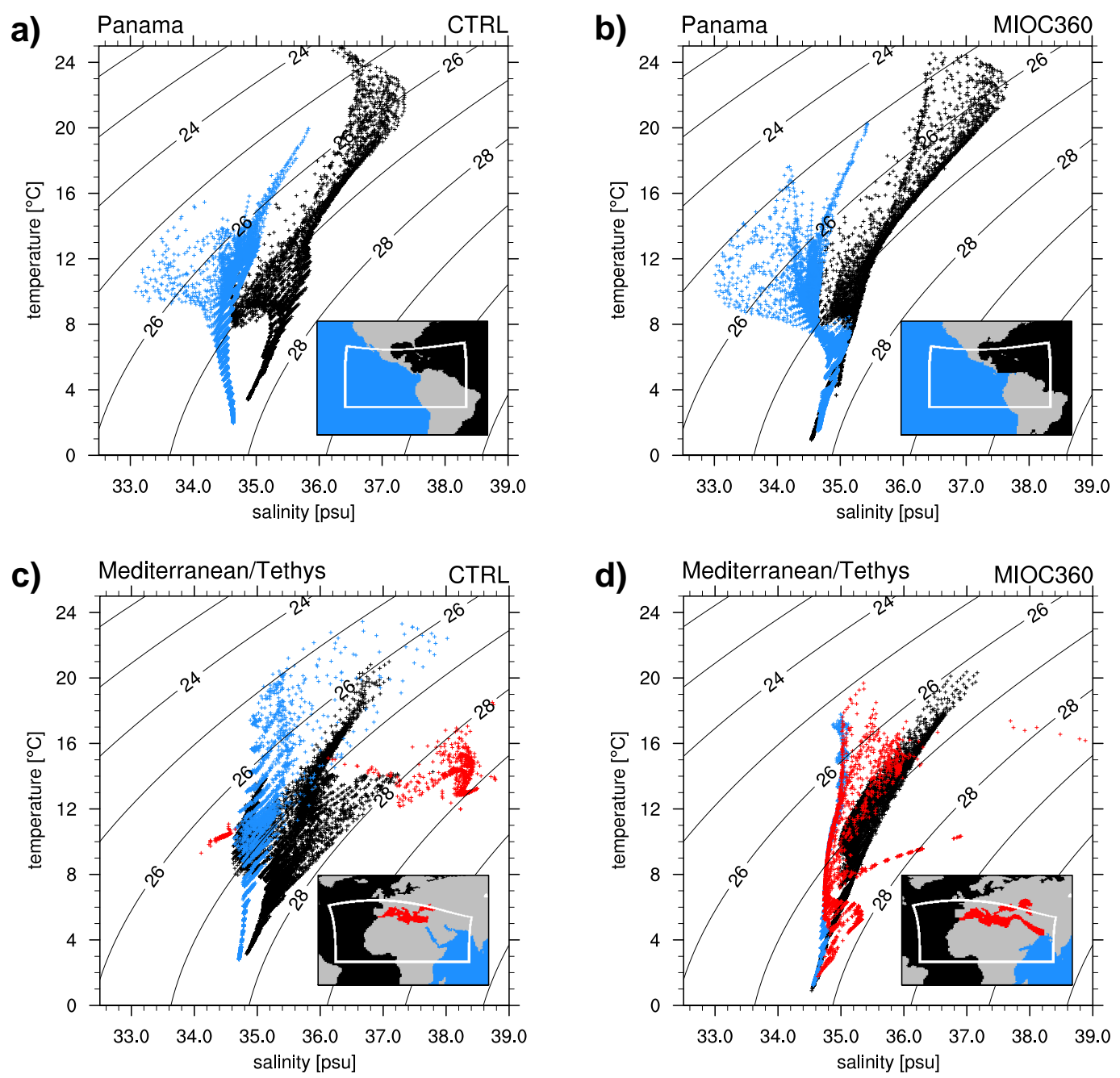

e)
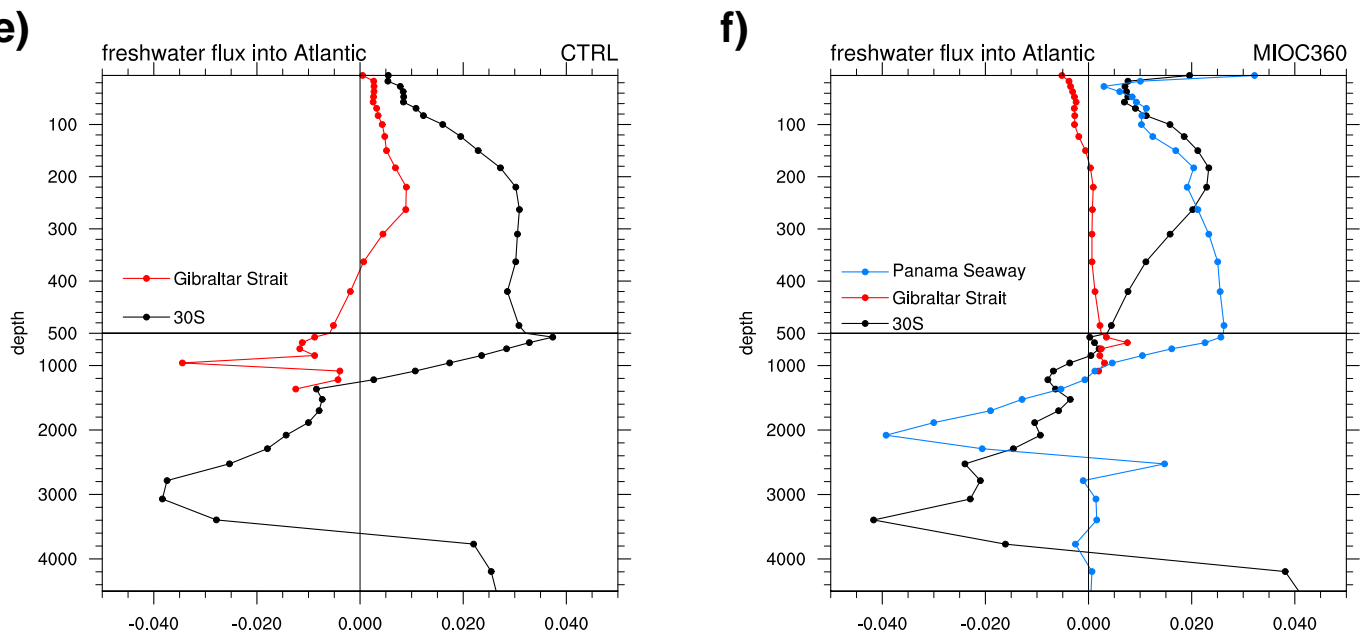

Fig. 12. T-S diagram for the water masses below $150 \mathrm{~m}$ in the vicinity of (a)-(b) the Panama Seaway and (c)-(d) the Mediterranean/Tethys for CTRL and MIOC360. Black crosses represent Atlantic Ocean water masses, blue crosses Pacific and Indian Ocean water, and red crosses Mediterranean/Tethys water. The in-line plots show the region for which the T-S pairs are obtained. (e)-(f) The freshwater flux through the Panama Seaway (blue), Gibraltar Strait (red), and at $30^{\circ} \mathrm{S}$ into the Atlantic Ocean relative to a salinity of 35.5 psu. Freshwater flux at each depth is weighted with the corresponding level thickness; the vertical sum equals the total freshwater flux. Note the different tickmarks for the upper $500 \mathrm{~m}$. 
a)

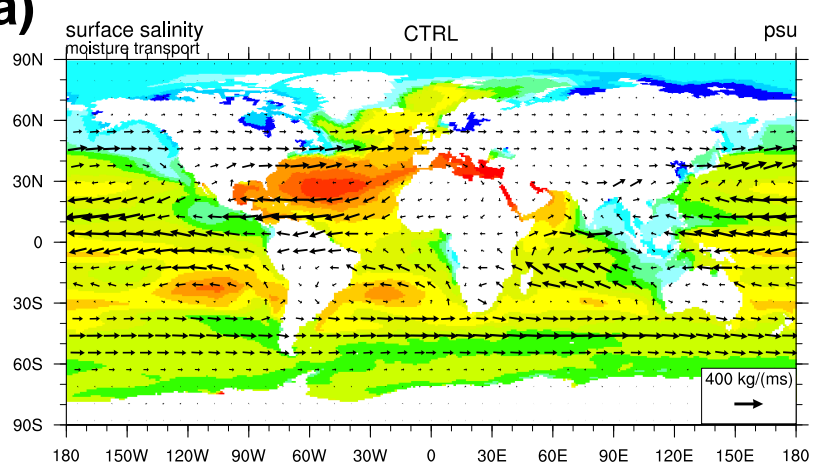

c)

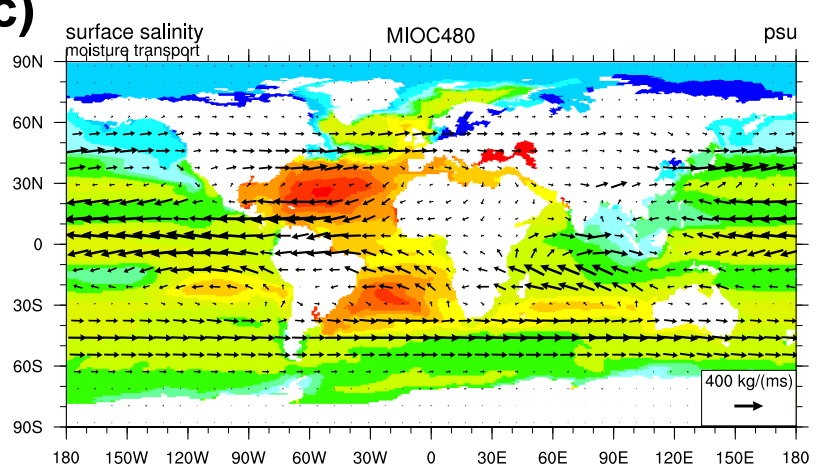

b)

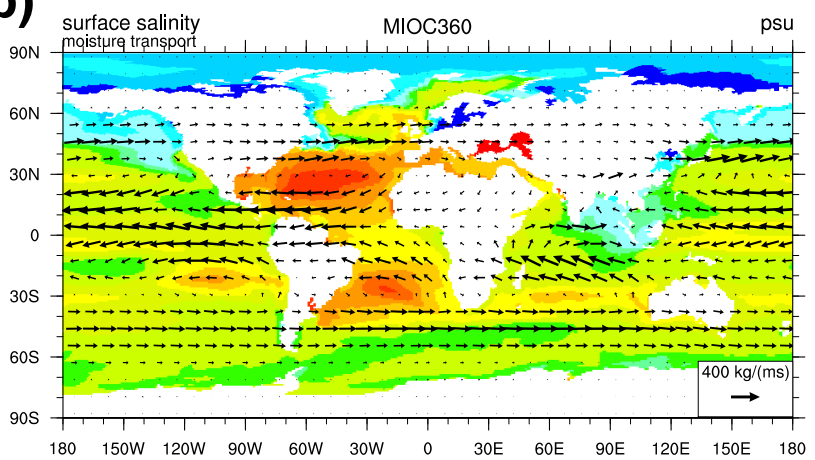

d)

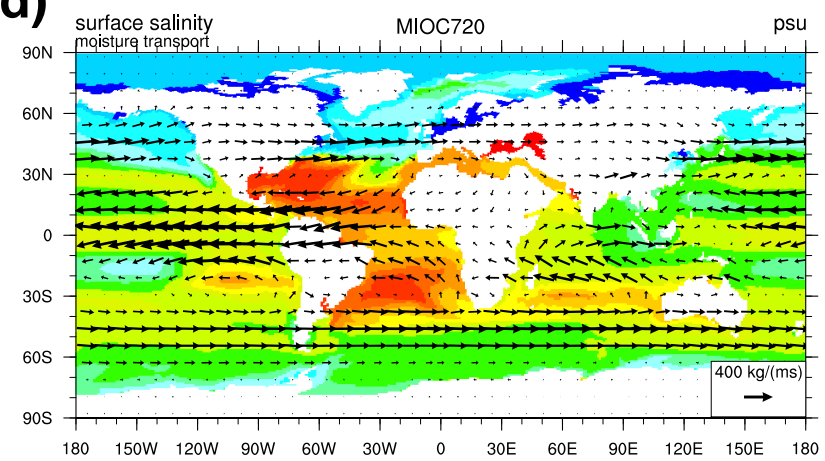

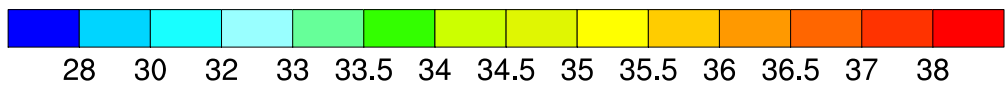

Fig. 13. Surface salinity for all experiments as contours (in psu). Overlaid as arrows is the vertically integrated moisture transport according to Eq. (4) (in $\mathrm{kg} /(\mathrm{m} \mathrm{s}))$.

temperature gradient. High latitude temperatures are generally too cold and low latitude temperatures are generally too warm.

\section{Discussion}

We perform the first fully coupled simulations for the warm Middle Miocene using the general circulation model MPIESM. The Middle Miocene topography induces a global warming of $0.7 \mathrm{~K}$ compared to today. The continental warming is larger because topography affects the continents, but does not affect the ocean surface. Uncertainties in the applied topography can, therefore, significantly alter surface temperatures. Especially mountain regions like the Andes, Rocky Mountains, and Himalayas are subject to errors in elevation (see Herold et al., 2008, Tables 1 and 2 for details).

If we increase atmospheric $\mathrm{CO}_{2}$ levels to 480 and $720 \mathrm{ppm}$ as in MIOC480 and MIOC720, we obtain a global warming of 2.8 and $4.9 \mathrm{~K}$. A stronger greenhouse effect and the associated water vapour feedback lead to a more humid climate with an enhanced hydrological cycle. The warming obtained by a doubling of $\mathrm{CO}_{2}$ is $4.0 \mathrm{~K}$ and much larger than in pre-
Table 4. References of marine proxy SST reconstructions.

\begin{tabular}{ll}
\hline source & reference \\
\hline DSDP 55 & Douglas and Savin (1971) \\
DSDP 167 & Savin et al. (1975) \\
DSDP 279A and 281 & Shackleton and Kennett (1975) \\
ODP 903 and 905 & van der Smissen and Rullkötter (1996) \\
DSDP 588, 608, and ODP 730 & Pagani et al. (1999) \\
DSDP 588, 608, and ODP 883 & Ennyu (2003) \\
ODP 1170 and 1172 & Ennyu and Arthur (2004) \\
ODP 1170 and 1171 & Shevenell et al. (2004) \\
ODP 1092 & Kuhnert et al. (2009) \\
ODP 747 & Majewski (2010) \\
bivalvia shells & Oleinik et al. (2008) \\
bivalvia shells & Ennyu (2003) \\
\hline
\end{tabular}

vious studies, which is $2.0 \mathrm{~K}$ in You et al. (2009) and $2.3 \mathrm{~K}$ in Tong et al. (2009). The larger value may be explained by a higher climate sensitivity of the MPI-ESM compared to the model used by You et al. and Tong et al.. However, our sensitivity is within the range of the model sensitivities obtained from Henrot et al. (2010), although their hydrological cycle is more sensitive. 

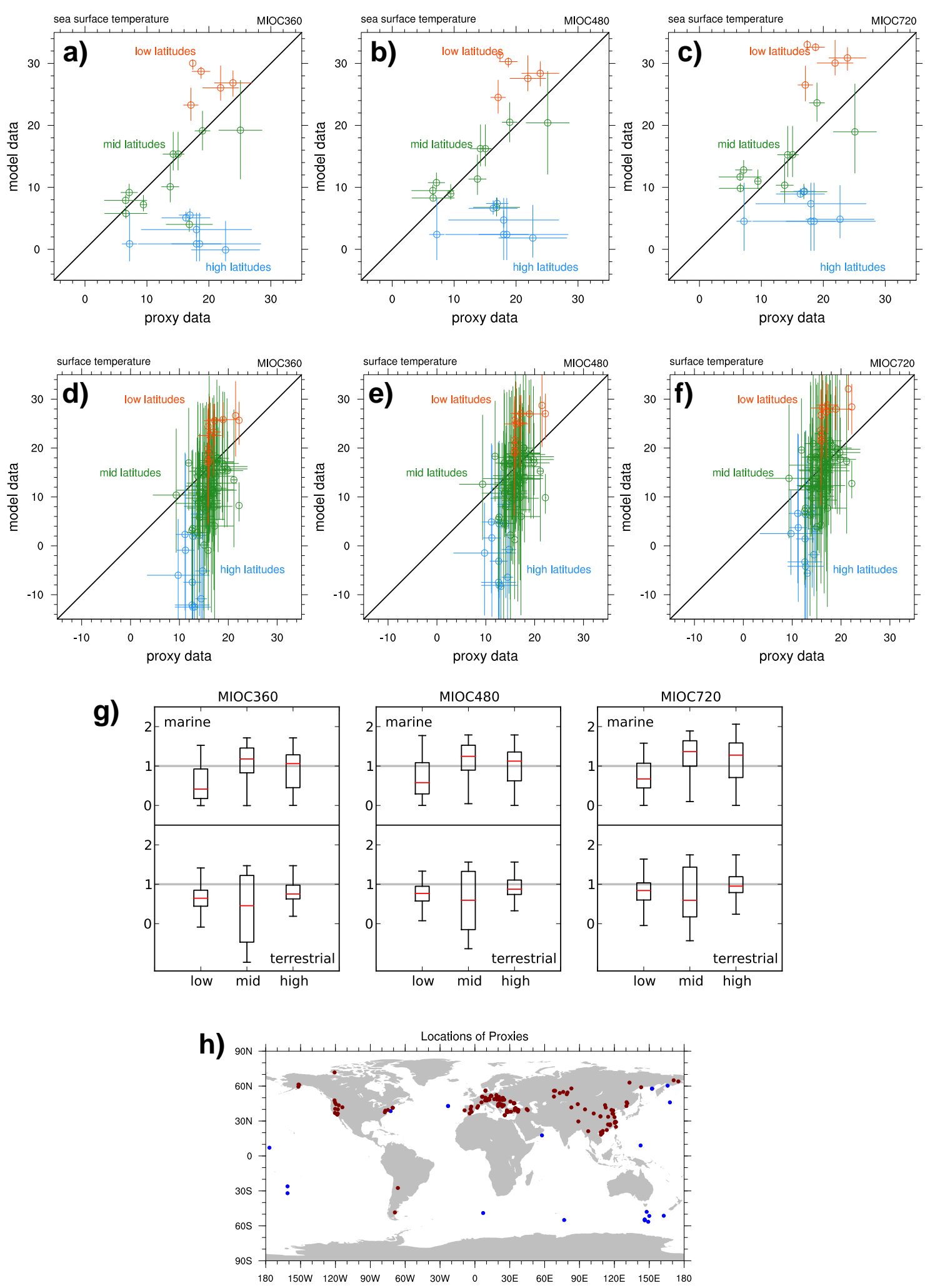

Fig. 14. Comparison of model output with (a)-(c) terrestrial and (d)-(f) marine temperature reconstructions. The low latitudes are defined to be between the equator and $30^{\circ} \mathrm{N} / \mathrm{S}$, midlatitudes are between 30 and $55^{\circ} \mathrm{N} / \mathrm{S}$, and high latitudes are poleward of $55^{\circ} \mathrm{N} / \mathrm{S}$. (g) Box plot of model-to-data temperature ratios for each grid box, separated for marine and terrestrial proxies as well as for low, mid-, and high latitudes. Values near 1 correspond to a good agreement, while values greater (smaller) than 1 show that the model is too warm (cold). The red line corresponds to the mean of the distribution. (h) The location of the proxies. 
Our experiments could not reproduce the flatter equatorto-pole temperature gradient that has been reconstructed for sea surface and land surface temperatures (Nikolaev, 2006; Bruch et al., 2007). A comparison to proxy data shows that the low latitude temperatures are too high and that the high latitude temperatures are too low. Although sparser, marine proxies are more widely spread than terrestrial proxies, which are hardly available in the Southern Hemisphere, for example in Africa or in Australia. To improve model-data validation, more low and high-latitude terrestrial proxies are needed.

As shown in Stewart et al. (2004), well-preserved foraminifera reveal lower tropical temperatures than previously stated. Thus, estimates from older reconstructions could underestimate tropical sea surface temperatures. It is also known that sea surface temperature reconstructions for the Eocene are biased toward colder temperature (Pearson et al., 2007). A revision of the low-latitude marine proxies, especially those from older reconstructions, would be appropriate.

Although open ocean gateways support large-scale mixing between the adjacent ocean basins, against expectations, the AMOC in our model is insensitive to these water mass composition changes. In MIOC 360 and MIOC480, the AMOC is as strong as today. It extends to the high latitudes, because the absent Greenland-Scotland Ridge cannot act as a barrier. The flow through the Panama Seaway is directed from the Pacific into the Atlantic, confirming the results of an idealised study for the early Miocene (von der Heydt and Dijkstra, 2006). Instead of a reduced salinity contrast between Pacific and Atlantic Ocean, we find a stronger salinity contrast. The inflow of relative fresh Pacific surface water is overcompensated for by an increased moisture transport from the Atlantic into the Pacific. This enhanced salinity contrast supports a meridional overturning circulation that is as strong as today. Previous model studies for an open Panama Seaway, reflecting the Pliocene period, report a collapse of the AMOC (Maier-Reimer et al., 1990), or a very weak overturning circulation (Lunt et al., 2007). In a recent review paper, Molnar (2008) discussed evidence from reconstructions and from model studies and concluded that the closing of the Panama Seaway "seems no more than a bit player in global climate change". Of course, the situation in our simulations is different, because of the open Tethys. We find that Tethys water is somewhat "neutral" regarding the freshwater transport and therefore, does not significantly contribute to the enhanced salinity contrast between Atlantic and Pacific Ocean. However, Molnar is right in the sense that open ocean gateways alone do not explain the Middle Miocene warming.

In our warmest climate MIOC720, the AMOC severely slows down to about $4 \mathrm{~Sv}$. The surface ocean of the North Atlantic is fed by runoff into the North Sea and from the North American East Coast. Ocean stratification increases and inhibits North Atlantic deepwater formation. In comparison to global warming scenarios where the ECHAM5/MPI-OM model shows a reduction of only $30 \%$ in the A1B scenario, the Miocene setup is apparently more sensitive (Jungclaus et al., 2006).

Because the AMOC also transports heat from low to high latitudes, any changes alter global poleward heat transport. However, as storm tracks intensify in a warmer climate, the associated moist transient eddy transport compensates for the decreased ocean heat transport. We claim that this compensation can be compared to the Bjerknes compensation, though not for deviations from the mean state but for different mean states of the climate system. A similar compensating effect has also been found for the Late Miocene climate (Micheels et al., 2011). They show that ocean heat transport decreases because of the open Panama Seaway. On the contrary, we show that ocean heat transport only decreases if the AMOC collapses as in MIOC720.

Just like the ocean circulation, the atmospheric circulation reorganises. Ocean and atmospheric heat transport change, but the total heat transport remains nearly unchanged because oceanic and atmospheric heat transport compensate. A reduction of the equator-to-pole temperature gradient is, therefore, unlikely caused by a reorganised ocean circulation, as it has been claimed earlier (Pagani et al., 1999). Instead, we find that changes in the local energy balance, for example due to a smaller surface albedo, a lower topography, or higher $\mathrm{CO}_{2}$, explain the warmer high latitudes.

Larger high latitude temperatures and higher atmospheric $\mathrm{CO}_{2}$ levels provide good conditions for plant growth. Because our model includes a dynamic vegetation module, we are able to simulate the interactions and feedbacks between the vegetation and the climate system. We find that boreal forests expand northward into the high latitudes, which is in line with vegetation reconstructions (Wolfe, 1985; Williams et al., 2008). In contrast, the desert cover of the Saharan region disagrees with reconstructions (Senut et al., 2009). The problem is that we have to prescribe soil properties, the vegetation model in JSBACH does not include a dynamic soil model. To overcome this, globally or zonally averaged values would be a more appropriate choice and allow a "level playing field". A recent model study shows that a dynamic background albedo scheme for JSBACH improves rainfall over the Sahel/Sahara region, which, applied to the mid Holocene (6000 yr ago), leads to higher vegetation variability (Vamborg et al., 2011). In a sensitivity study for the Late Miocene, Micheels et al. (2009) showed that a modern Sahara leads to a cooling in the northern high latitudes. We, therefore, expect a further high latitude warming if North Africa is covered by vegetation. Because the dense vegetation in our simulations requests warmer temperatures and higher $\mathrm{CO}_{2}$ levels, we assume that the warm Middle Miocene climate depends on higher than present-day $\mathrm{CO}_{2}$ levels. However, the warming due to high-latitude vegetation feedbacks is restricted by the maximum possible vegetation cover. A recent study showed that boreal afforestation in a pre-industrial setup leads to a global warming of $0.25 \mathrm{~K}$ (Bathiany et al., 2010). High 
latitude feedbacks, namely the ice-albedo and the vegetation feedback are too weak to decrease the equator-to-pole temperature gradient.

\section{Conclusions}

To conclude, we propose that full ocean dynamics cannot be held responsible for a global redistribution of heat to higher latitudes because of the complex ocean-atmosphere interactions. The total poleward heat transport changes only a little because of a Bjerknes-compensation-like mechanism that makes high latitude warming difficult. Furthermore, high latitude feedbacks are too weak and cannot significantly contribute to a flatter equator-to-pole temperature gradient. The mismatch between model and proxy data leads to the conclusion that we do not fully understand how feedback mechanisms may work in a warmer climate. For the Middle Miocene, we conclude that the topographic boundary conditions are not sufficient to explain at least the global warming and that a warmer Middle Miocene climate without an enhanced greenhouse effect cannot be reproduced with our model.

Acknowledgements. This work has been accomplished within the project FOR 1070 Understanding Cenozoic Climate Cooling of the German Research Foundation (DFG). All model integrations were performed at the high- performance computing platforms of the German Climate Computing Centre (DKRZ) in Hamburg. We would like to thank Helmuth Haak for helping to set up the model, Torsten Utescher for providing the terrestrial proxy data, and Victor Brovkin for proofreading the manuscript. We thank Nicolas Herold and an anonymous reviewer for their helpful comments to improve the final version of this manuscript.

The service charges for this open access publication have been covered by the Max Planck Society.

Edited by: A. A. Haywood

\section{References}

Bathiany, S., Claussen, M., Brovkin, V., Raddatz, T., and Gayler, V.: Combined biogeophysical and biogeochemical effects of largescale forest cover changes in the MPI earth system model, Biogeosciences, 7, 1383-1399, doi:10.5194/bg-7-1383-2010, 2010.

Bjerknes, J.: Atlantic air-sea interaction, Adv. Geophys., 10, 1-82, 1964.

Blackmon, M.: A climatological spectral study of the $500 \mathrm{mb}$ geopotential height of the Northern Hemisphere, J. Atmos. Sci., 33, 1607-1623, doi:10.1175/15200469(1976)033<1607:ACSSOT > 2.0.CO;2, 1976.

Böhme, M., Winklhofer, M., and Ilg, A.: Miocene precipitation in Europe: Temporal trends and spatial gradients, Palaeogeogr. Palaeocl., 304, 212-218, doi:10.1016/j.palaeo.2010.09.028, 2011.

Brovkin, V., Raddatz, T., Reick, C., Claussen, M., and Gayler, V.: Global biogeophysical interactions between forest and climate,
Geophys. Res. Lett., 36, L07405, doi:10.1029/2009GL037543, 2009.

Bruch, A., Uhl, D., and Mosbrugger, V.: Miocene climate in Europe-Patterns and evolution:: A first synthesis of NECLIME, Palaeogeogr. Palaeocl., 253, 1-7, doi:10.1016/j.palaeo.2007.03.030, 2007.

Bruch, A., Utescher, T., and Mosbrugger, V.: Precipitation patterns in the Miocene of Central Europe and the development of continentality, Palaeogeogr. Palaeocl., 304, 202-211, doi:10.1016/j.palaeo.2010.10.002, 2010.

Butzin, M., Lohmann, G., and Bickert, T.: Miocene ocean circulation inferred from marine carbon cycle modeling combined with benthic isotope records, Paleoceanography, 26, PA1203, doi:10.1029/2009PA001901, 2011.

Douglas, R. and Savin, S.: Isotopic Analysis of Planktonic Foraminifera from the Cenozoic of the Northwest Pacific, Leg 6, Initial Rep. Deep Sea, 6, 1123-1127, doi:10.2973/dsdp.proc.6.1971, 1971.

Emiliani, C. and Edwards, G.: Tertiary Ocean Bottom Temperatures, Nature, 171, 887-888, 1953.

Ennyu, A.: Middle miocene climate evolution in the pacific realm, Ph.D. thesis, The Pennsylvania State University, 2003.

Ennyu, A. and Arthur, M.: The Cenozoic Southern Ocean: tectonics, sedimentation, and climate change between Australia and Antarctica, chap. Early to Middle Miocene Paleoceanography in the Southern High Latitudes Off Tasmania, American Geophysical Union, p.215, 2004.

Hastings, D., Russell, A., and Emerson, S.: Foraminiferal magnesium in Globeriginoides sacculifer as a paleotemperature proxy, Paleoceanography, 13, 161-169, doi:10.1029/97PA03147, 1998.

Heinemann, M.: Warm and sensitive Paleocene-Eocene climate, Ph.D. thesis, Max-Planck-Institut für Meteorologie, 2009.

Heinemann, M., Jungclaus, J. H., and Marotzke, J.: Warm Paleocene/Eocene climate as simulated in ECHAM5/MPI-OM, Clim. Past, 5, 785-802, doi:10.5194/cp-5-785-2009, 2009.

Henrot, A.-J., Franois, L., Favre, E., Butzin, M., Ouberdous, M., and Munhoven, G.: Effects of $\mathrm{CO}_{2}$, continental distribution, topography and vegetation changes on the climate at the Middle Miocene: a model study, Clim. Past, 6, 675-694, doi:10.5194/cp6-675-2010, 2010.

Herold, N., Seton, M., Müller, R., You, Y., and Huber, M.: Middle Miocene tectonic boundary conditions for use in climate models, Geochem. Geophy. Geosy., 9, Q10009, doi:10.1029/2008GC002046, 2008.

Herold, N., Müller, R., and Seton, M.: Comparing early to middle Miocene terrestrial climate simulations with geological data Geosphere, 6, 952-961, doi:10.1130/GES00544.1, 2010.

Hibler, W.: A Dynamic Thermodynamic Sea Ice Model, J. Phys. Oceanogr., 9, 815-846, doi:10.1175/15200485(1979)009<0815:ADTSIM > 2.0.CO;2, 1979.

IPCC: Contribution of Working Group I to the Fourth Assessment Report of the Intergovernmental Panel on Climate Change, 2007, Cambridge University Press, Cambridge, UK and New York, NY, USA, 2007.

Jungclaus, J., Botzet, M., Haak, H., Marotzke, J., Mikolajewicz, U., Roeckner, E., Keenlyside, N., Latif, M., and Luo, J.: Ocean Circulation and Tropical Variability in the Coupled Model ECHAM5/MPI-OM, J. Climate, 19, 3952-3972, doi:10.1175/JCLI3827.1, 2006. 
Kuhnert, H., Bickert, T., and Paulsen, H.: Southern Ocean frontal system changes precede Antarctic ice sheet growth during the middle Miocene, Earth Planet. Sc. Lett., 284, 630-638, doi:10.1016/j.epsl.2009.05.030, 2009.

Kürschner, W., Kvaček, Z., and Dilcher, D.: The impact of Miocene atmospheric carbon dioxide fluctuations on climate and the evolution of terrestrial ecosystems, P. Natl. Acad. Sci., 105, 449, doi:10.1073/pnas.0708588105, 2008.

Leduc, G., Vidal, L., Tachikawa, K., Rostek, F., Sonzogni, C., Beaufort, L., and Bard, E.: Moisture transport across Central America as a positive feedback on abrupt climatic changes, Nature, 445, 908-911, doi:10.1038/nature05578, 2007.

Lunt, D., Valdes, P., Haywood, A., and Rutt, I.: Closure of the Panama Seaway during the Pliocene: implications for climate and Northern Hemisphere glaciation, Clim. Dynam., 30, 1-18, doi:10.1007/s00382-007-0265-6, 2007.

Maier-Reimer, E., Mikolajewicz, U., and Crowley, T.: Ocean General Circulation Model Sensitivity Experiment with an open Central American Isthmus, Paleoceanography, 5, 349-366, doi:10.1029/PA005i003p00349, 1990.

Majewski, W.: Planktonic Foraminiferal Response to Middle Miocene Cooling in the Southern Ocean (ODP Site 747, Kerguelen Plateau), Acta Palaeontol. Polon., 55, 541-560, doi:10.4202/app.2009.0088, 2010.

Marsland, S. J., Haak, H., Jungclaus, J. H., Latif, M., and Röske, F.: The Max-Planck-Institute global ocean/sea ice model with orthogonal curvilinear coordinates, Ocean Modell. 5, 91-127, doi:10.1016/S1463-5003(02)00015-X, 2003.

Micheels, A., Eronen, J., and Mosbrugger, V.: The Late Miocene climate response to a modern Sahara desert, Global Planet. Change, 67, 193-204, doi:10.1016/j.gloplacha.2009.02.005, 2009.

Micheels, A., Bruch, A., Eronen, J., Fortelius, M., Harzhauser, M., Utescher, T., and Mosbrugger, V.: Analysis of heat transport mechanisms from a Late Miocene model experiment with a fully-coupled atmosphere-ocean general circulation model, Palaeogeogr. Palaeocl., 304, 337-350, doi:10.1016/j.palaeo.2010.09.021, 2011.

Molnar, P.: Closing of the Central American Seaway and the Ice Age: A critical review, Paleoceanography, 23, PA2201, doi:10.1029/2007PA001574, 2008.

Mosbrugger, V. and Utescher, T.: The coexistence approach a method for quantitative reconstructions of Tertiary terrestrial palaeoclimate data using plant fossils, Palaeogeogr. Palaeocl., 134, 61-86, 1997.

Myhre, G., Highwood, E., Shine, K., and Stordal, F.: New estimates of radiative forcing due to well mixed greenhouse gases, Geophys. Res. Lett., 25, 2715-2718, doi:10.1029/98GL01908, 1998.

Nikolaev, S.: Principal features of the World Ocean climate change in the Cenozoic and their possible causes, Oceanology, 46, 513525, doi:10.1134/S0001437006040084, 2006.

Nisancioglu, K., Raymo, M., and Stone, P.: Reorganization of Miocene deep water circulation in response to the shoaling of the Central American Seaway, Paleoceanography, 18, 1006, doi:10.1029/2002PA000767, 2003.

Oleinik, A., Marincovich Jr., K., and Swart, P.: Magnitude of Middle Miocene warming in North Pacific high latitudes: stable isotope evidence from Kaneharaia (Bivalvia, Dosiniinae), Bull.
Geol. Surv. Jpn., 59, 339-353, 2008.

Pagani, M., Arthur, M., and Freeman, K.: Miocene evolution of atmospheric carbon dioxide, Paleoceanography, 14, 273-292, doi:10.1029/1999PA900006, 1999.

Pearson, P., Van Dongen, B., Nicholas, C., Pancost, R., Schouten, S., Singano, J., and Wade, B.: Stable warm tropical climate through the Eocene Epoch, Geology, 35, 211-214, doi:10.1130/G23175A.1, 2007.

Raddatz, T., Reick, C., Knorr, W., Kattge, J., Roeckner, E., Schnur, R., Schnitzler, K., Wetzel, P., and Jungclaus, J.: Will the tropical land biosphere dominate the climate - carbon cycle feedback during the twenty-first century?, Clim. Dynam., 29, 565-574, doi:10.1007/s00382-007-0247-8, 2007.

Raymo, M.: The Himalayas, organic carbon burial, and climate in the Miocene, Paleoceanography, 9, 399-404, doi:10.1029/94PA00289, 1994.

Roeckner, E., Bäuml, G., Bonaventura, L., Brokopf, R., and Esch, M.: The Atmospheric General Circulation Model Echam5, Part I: Model Description, Tech. rep., Max-Planck Institute for Meteorology, 2003.

Roeckner, E., Brokopf, R., Esch, M., Giorgetta, M., Hagemann, S., Kornblueh, L., Manzini, E., Schlese, U., and Schulzweida, U.: Sensitivity of Simulated Climate to Horizontal and Vertical Resolution in the ECHAM5 Atmosphere Model, J. Climate, 19, 3771-3791, 2006.

Royer, D., Wing, S., Beerling, D., Jolley, D., Koch, P., Hickey, L., and Berner, R.: Paleobotanical Evidence for Near Present-Day Levels of Atmospheric $\mathrm{CO}_{2}$ During Part of the Tertiary, Science, 292, 2310-2313, doi:10.1126/science.292.5525.2310, 2001.

Savin, S., Douglas, R., and Stehli, F.: Tertiary marine paleotemperatures, Bull. Geol. Soc. Am., 86, 1499-1510, doi:10.1130/00167606(1975)86<1499:TMP>2.0.CO;2, 1975.

Semtner, A. J.: A Model for the Thermodynamic Growth of Sea Ice in Numerical Investigations of Climate, J. Phys. Oceanogr., 6, 379-389, doi:10.1175/15200485(1976)006<0379:AMFTTG > 2.0.CO;2, 1976.

Senut, B., Pickford, M., and Ségalen, L.: Neogene desertification of Africa, Compt. Rend. Geosci., 341, 591-602, doi:10.1016/j.crte.2009.03.008, 2009.

Shackleton, N. and Kennett, J.: Paleotemperature History of the Cenozoic and the Initiation of Antarctic Glaciation: Oxygen and Carbon Isotope Analyses in DSDP Sites 277, 279 and 281, Initial Rep. Deep Sea, 29, 743-755, doi:10.2973/dsdp.proc.29.1975, 1975.

Shevenell, A., Kennett, J., and Lea, D.: Middle Miocene Southern Ocean Cooling and Antarctic Cryosphere Expansion, Science, 305, 1766-1770, doi:10.1126/science.1100061, 2004.

Stewart, D., Pearson, P., Ditchfield, P., and Singano, J.: Miocene tropical Indian Ocean temperatures: evidence from three exceptionally preserved foraminiferal assemblages from Tanzania, J. Afr. Earth Sci., 40, 173-189, doi:10.1016/j.jafrearsci.2004.09.001, 2004.

Tong, J., You, Y., Müller, R., and Seton, M.: Climate model sensitivity to atmospheric $\mathrm{CO}_{2}$ concentrations for the middle Miocene, Global Planet. Change, 67, 129-140, doi:10.1016/j.gloplacha.2009.02.001, 2009.

Trenberth, K. and Fasullo, J.: Global warming due to increasing absorbed solar radiation, Geophys. Res. Lett., 36, L07706, doi:10.1029/2009GL037527, 2009. 
Uppala, S. M., KÅllberg, P. W., Simmons, A. J., Andrae, U., Bechtold, V. D. C., Fiorino, M., Gibson, J. K., Haseler, J., Hernandez, A., Kelly, G. A., Li, X., Onogi, K., Saarinen, S., Sokka, N., Allan, R. P., Andersson, E., Arpe, K., Balmaseda, M. A., Beljaars, A. C. M., Berg, L. V. D., Bidlot, J., Bormann, N., Caires, S., Chevallier, F., Dethof, A., Dragosavac, M., Fisher, M., Fuentes, M., Hagemann, S., Hólm, E., Hoskins, B. J., Isaksen, L., Janssen, P. A. E. M., Jenne, R., Mcnally, A. P., Mahfouf, J.-F., Morcrette, J.-J., Rayner, N. A., Saunders, R. W., Simon, P., Sterl, A., Trenberth, K. E., Untch, A., Vasiljevic, D., Viterbo, P., and Woollen, J.: The ERA-40 re-analysis, Q. J. Roy. Meteorol. Soc., 131, 2961-3012, doi:10.1256/qj.04.176, 2005.

Utescher, T., Böhme, M., and Mosbrugger, V.: The Neogene of Eurasia: Spatial gradients and temporal trends - The second synthesis of NECLIME, Palaeogeogr. Palaeocl., 304, 196-201, doi:10.1016/j.palaeo.2011.03.012, 2011.

Valcke, S.: OASIS3 User Guide (prism_2-5), Tech. Rep. 3, PRISM, http://www.prism.enes.org/Publications/Reports/all_editions/ index.php\#report02, last access: July 2010, 2006.

Vamborg, F. S. E., Brovkin, V., and Claussen, M.: The effect of a dynamic background albedo scheme on Sahel/Sahara precipitation during the mid-Holocene, Clim. Past, 7, 117-131, doi:10.5194/cp-7-117-2011, 2011.

van der Smissen, J. and Rullkötter, J.: Organofacies variations in sediments from the continental slope and rise of the New Jersey continental margin (Sites 903 and 905), in: Proceedings of the Ocean Drilling Program, Scientific results, doi:10.2973/odp.proc.sr.150.040.1996, 1996. von der Heydt, A. and Dijkstra, H.: Effect of ocean gateways on the global ocean circulation in the late Oligocene and early Miocene, Paleoceanography, 21, PA1011, doi:10.1029/2005PA001149, 2006.

Williams, C. J., Mendell, E. K., Murphy, J., Court, W. M., Johnson, A. H., and Richter, S. L.: Paleoenvironmental reconstruction of a Middle Miocene forest from the western Canadian Arctic, Palaeogeogr. Palaeocl., 261, 160-176, doi:10.1016/j.palaeo.2008.01.014, 2008.

Wolfe, J.: The Carbon Cycle and Atmospheric $\mathrm{CO}_{2}$ : Natural Variations Archean to Present, chap. Distribution of major vegetational types during the Tertiary, American Geophysical Union, Washington, DC, 357-375, 1985.

Yin, J.: A consistent poleward shift of the storm tracks in simulations of 21 st century climate, Geophys. Res. Lett., 32, L18701, doi:10.1029/2005GL023684, 2005.

You, Y., Huber, M., Müller, D., Poulsen, C., and Ribbe, J.: Simulation of the Middle Miocene Climate Optimum, Geophys. Res. Lett., 36, L04702, doi:10.1029/2008GL036571, 2009.

Zachos, J., Pagani, M., Sloan, L., Thomas, E., and Billups, K.: Trends, rhythms, and aberrations in global climate $65 \mathrm{Ma}$ to present, Science, 292, 686-693, doi:10.1126/science.1059412, 2001.

Zaucker, F. and Broecker, W.: The Influence of Atmospheric Moisture Transport on the Fresh Water Balance of the Atlantic Drainage Basin: General Circulation Model Simulations and Observations, J. Geophys. Res., 97, 2765-2773, 1992. 